\title{
Bone Morphogenetic Protein-2 in Development and Bone Homeostasis
}

\author{
Daniel Halloran ${ }^{\circledR}$, Hilary W. Durbano and Anja Nohe * \\ Department of Biological Sciences, University of Delaware, Newark, DE 19716, USA; dhallor@udel.edu (D.H.); \\ weidnerh@udel.edu (H.W.D.) \\ * Correspondence: anjanohe@udel.edu; Tel.: +1-302-831-6977
}

Received: 13 August 2020; Accepted: 11 September 2020; Published: 13 September 2020

\begin{abstract}
Bone morphogenetic proteins (BMPs) are multi-functional growth factors belonging to the Transforming Growth Factor-Beta (TGF- $\beta$ ) superfamily. These proteins are essential to many developmental processes, including cardiogenesis, neurogenesis, and osteogenesis. Specifically, within the BMP family, Bone Morphogenetic Protein-2 (BMP-2) was the first BMP to be characterized and has been well-studied. BMP-2 has important roles during embryonic development, as well as bone remodeling and homeostasis in adulthood. Some of its specific functions include digit formation and activating osteogenic genes, such as Runt-Related Transcription Factor 2 (RUNX2). Because of its diverse functions and osteogenic potential, the Food and Drug Administration (FDA) approved usage of recombinant human BMP-2 (rhBMP-2) during spinal fusion surgery, tibial shaft repair, and maxillary sinus reconstructive surgery. However, shortly after initial injections of rhBMP-2, several adverse complications were reported, and alternative therapeutics have been developed to limit these side-effects. As the clinical application of BMP-2 is largely implicated in bone, we focus primarily on its role in bone. However, we also describe briefly the role of BMP-2 in development. We then focus on the structure of BMP-2, its activation and regulation signaling pathways, BMP-2 clinical applications, and limitations of using BMP-2 as a therapeutic. Further, this review explores other potential treatments that may be useful in treating bone disorders.
\end{abstract}

Keywords: development; BMP-2; CK2; CK2.3; osteoporosis; osteoblasts; osteoclasts; Smad1/5/8

\section{Introduction}

Bone Morphogenetic Proteins (BMPs) are multi-functional growth factors belonging to the Transforming Growth Factor-Beta (TGF- $\beta$ ) superfamily, which is also shared by Growth Differentiation Factors (GDFs), Glial-derived Neurotrophic Factors (GDNFs), Lefty, Inhibins, Activins, Nodal, and Mülllerian Inhibiting Substance (MIS) [1-5]. Currently, over 20 BMPs have been identified, making these proteins the largest subgroup within the TGF- $\beta$ superfamily. BMPs have crucial functions in developmental processes, such as cardiogenesis, digit apoptosis, somite formation, neurogenesis, eye formation, and musculoskeletal development [6-13]. Additionally, BMPs are expressed throughout adulthood, contributing to osteogenesis, adipogenesis, chondrogenesis, programmed cell death, cardiac differentiation, and nervous system maintenance [14-26]. The first BMP was identified in bone in 1965 by Marshall Urist and named BMP-2 [27]. Since then, BMP-2 has been well-characterized and many of its functions in bone and throughout the body have been elucidated. Because BMP-2 has been extensively studied and characterized, especially during development and in bone, this review will focus on BMP-2 in development and osteogenesis.

After identifying BMP-2, subsequent studies focused on BMP-2 and demonstrated its critical role during and after development. In early development, BMP-2 is critical for successful digit formation, cardiogenesis, neuronal growth, and many other processes $[6,20-22,25,28-30]$. It is continuously 
expressed into adulthood, where it induces processes such as intramembranous and endochondral ossification [2,27,31,32]. Additionally, BMP-2 is expressed in many cells throughout the body, such as osteocytes and osteoblasts [33]. Further elucidating the mechanism of BMP-2, Knockouts (KOs) and conditional KOs of BMP-2 in mice led to lethality or underdeveloped bones with reduced radial bone thickness, strength, and increased risk of spontaneous fractures; further, these KOs presented heart deficiencies, chondrocyte abnormalities, and reduced vasculature [14,32,34-37].

BMP-2 has additional essential functions in the musculoskeletal system. Bone itself is a very dynamic and complex organ. The human skeleton provides protection of vital organs, structure, locomotion through anchoring of muscles, and mineral homeostasis [36]. Five major types of bone comprise the skeleton and dependent on their size and shape, these bones exert specific functions. Classified based on their shape, they include short (carpals), flat (ribs), long (femur), irregular (vertebrae), and sesamoid bones (patella). Each of these bone types have a specific function based upon their overall shape and morphology. In addition, each bone has four major layers of bone tissue: the periosteum is the outermost protective layer; cortical or compact bone is the outer dense shell located underneath the periosteum; cancellous or trabecular bone, also known as spongy bone, is located on the inside of the cortical shell; and finally there is the marrow cavity where important or critical stem cells, such as mesenchymal stem cells (MSCs) and hematopoietic stem cells (HSCs), are located [38,39]. The marrow cavity is vital, because as adults age, the locations of stem cells diminish, leading to complete reliance on the bone marrow cavities to promote differentiation of these pivotal cells. HSCs and MSCs differentiate into bone cells that are responsible for resorbing back old or damaged bone and building new bone, however, they are also responsible for differentiating cells into adipocytes or fat cells [40,41]. While adipocytes are important for bone growth and remodeling, too many fat cells within the bone are detrimental as this causes increased porosity and decreased structural support. This leads to an increase risk of fractures and breaks within the bone. Therefore, the correct balance between bone resorption, bone formation, and fat cell formation is critical for the bone remodeling process [42].

Bone remodeling is a critical process and it occurs continuously in the adult skeleton. In fact, approximately $10 \%$ of human bone is remodeled every year [43]. The bone is remodeled by resorption of old bone by osteoclasts and formation of new bone by osteoblasts (Figure 1). Osteoclasts in this microenvironment function as innate immune cells, initiating inflammatory responses and resorbing old or damaged bone [44,45]. When new bone needs to be formed, MSCs can differentiate into osteoblasts, and these osteoblasts can become embedded in the bone as osteocytes, which provide additional bone support and structure [41]. The main factor that differentiates MSCs into osteoblasts is BMP-2, which is released within the bone matrix or serum during osteoclast-driven bone resorption (Figure 2). To differentiate MSCs into osteoblasts, BMP-2 binds to type I and type II serine/threonine kinase receptors on target cells, activating Smad (canonical) and non-Smad (non-canonical) signaling pathways, which ultimately activates osteogenic genes such as Runt-Related Transcription Factor 2 (RUNX2) and Osterix (Osx) [2]. Furthermore, BMP-2 is also important in stimulating osteoclastogenesis by directly differentiating osteoclast precursor cells into osteoclasts, and antagonizing BMP-2 led to the downregulation of this process [46,47]. As BMP-2 is important for MSC differentiation, osteogenesis, and osteoclastogenesis, recombinant human BMP-2 (rhBMP-2) was approved by the Food and Drug Administration (FDA) and is administered after lumbar spinal fusions in tapered or cylindrical interbody cages [48-51]. Although BMP-2 promotes fracture healing, several post-surgical complications arose, including ectopic bone formation, radiculitis, vertebral osteolysis, increased microfracture occurrence, low bone healing efficacy, and hematoma formation [48,52-57]. The molecular mechanisms implicating the ectopic bone induction process is not well understood; however, it is believed to follow a non-physiological pathway. There have been promising strides in this particular area of research, as Hashimoto and colleagues developed a novel imaging method that can help both visualize and determine ectopic bone formation pathways. This discovery will help to facilitate and direct BMP-2 induced ectopic bone formation in concert with other molecules, like PTH or IL-17; however, more research is needed [58]. Therefore, a new treatment for bone disorders must be 
developed. In this review paper, we will describe the structure of BMP-2, its role in development, and its receptors, along with how it is regulated by agonists and antagonists to activate various signaling pathways. Additionally, we will describe the regulation of BMP-signaling pathways and how this regulation led to current and alternative therapeutics for bone disorders. As the FDA has approved BMP-2 for use in skeletal disorders and fractures, bone and bone disorders will be the primary focus of this review.

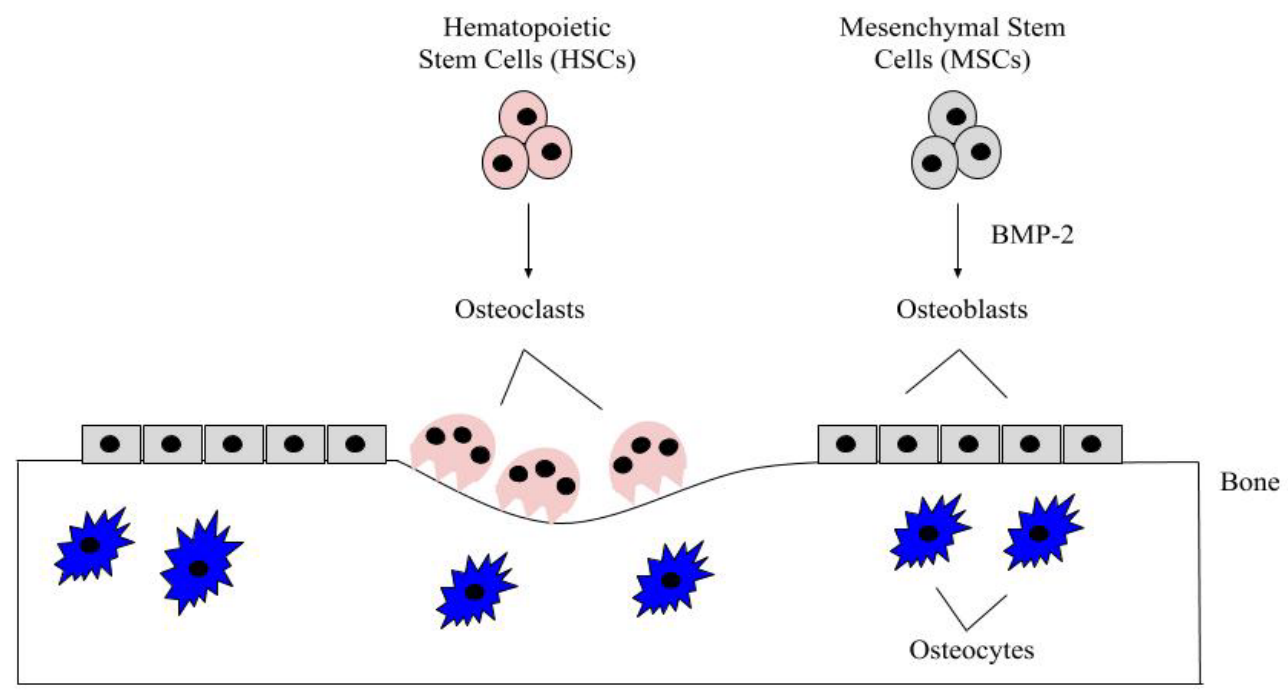

Figure 1. The bone microenvironment. Healthy bone function and renewal is controlled by the activity of osteoblasts and osteoclasts. Osteoblasts derive from MSCs, which commit to the osteoblast lineage after exposure to BMP-2. BMP-2 is secreted into the bone matrix or bloodstream by pre-existing osteoblasts, osteocytes, and endothelial cells, where it can bind to bone morphogenetic protein receptors (BMPRs) on MSCs. After MSCs differentiate into osteoblasts, these cells secrete the organic matrix of the bone. Some eventually become embedded within the bone as osteocytes, which provide further structure. HSCs differentiate into osteoclasts after being stimulated with factors, such as RANK-L and NF-kB. The osteoclasts are multinucleated and resorb the bone matrix, releasing contents (i.e., BMP-2 and calcium) to be recycled throughout the body.

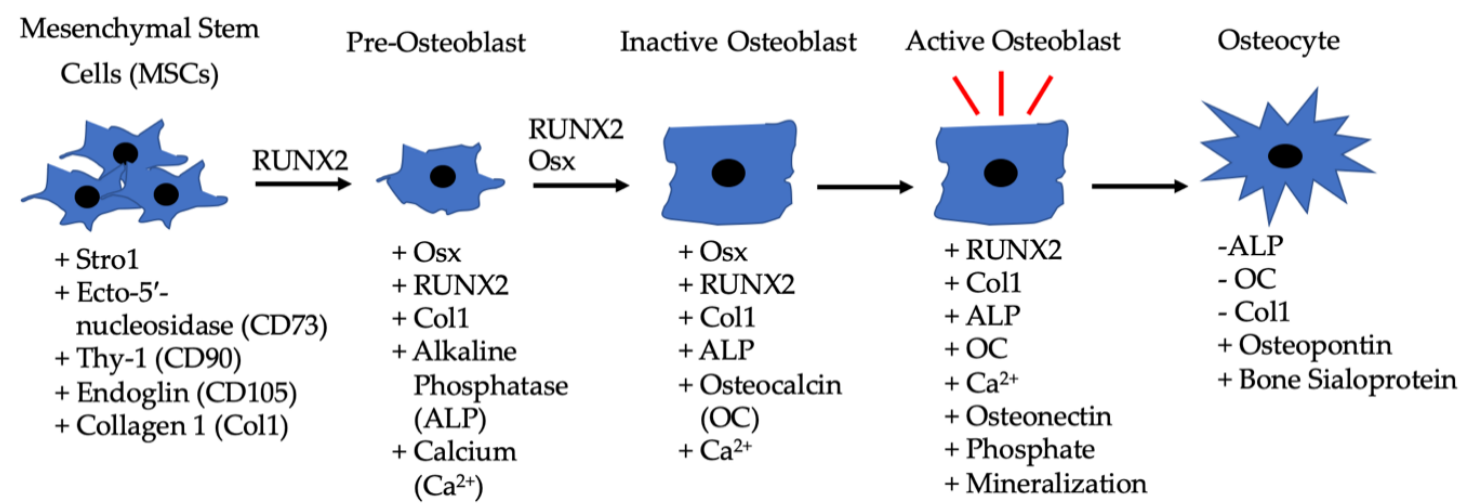

Figure 2. Differentiation of MSCs to osteoblasts driven by BMP-2, along with the other listed factors. MSCs are located in bone marrow and differentiate into pre-osteoblasts when exposed to RUNX2 and BMP-2. The pre-osteoblasts differentiate into inactive osteoblasts in the presence of RUNX2, BMP-2, and Osx. Inactive osteoblasts become active osteoblasts in bone microenvironments that require rebuilding, and BMP-2 can also assist in this process. Active osteoblasts can then become embedded in bone and function as osteocytes. 


\section{BMP-2 and Development}

BMP-2 has many roles during development. From the earliest stages of embryogenesis, BMP-2 regulates the formation of the dorsal/ventral (D/V) and anterior/posterior $(A / P)$ axes [59-62]. While regulating formation of the axes, BMP-2 is also involved in somite formation and somatic chondrogenesis, especially in the vertebral and axial skeleton [63-65]. Further, BMP-2 is crucial in nearly every stage of neural development and is essential for closure of the neural tube $[11,12,22,66]$. BMP- 2 is also involved in the development of the optical system. Specifically, it assists in the remodeling of the sclera as well as contributing to the formation of the retinal system $[13,67,68]$. However, overexpression of BMP-2 can lead to early myopia, and thus, its activity must be tightly regulated during embryogenesis and throughout development [67-69]. In addition to cell patterning, neurogenesis, and eye development, BMP-2 is involved in digit formation. BMP-2 assists in programmed cell death to initiate apoptosis in distal limbs, allowing for the formation of digits; lack of BMP-2 leads to the malformation of digits $[7,20,28,70]$. Simultaneously, BMP-2 is involved in formation of the mesoderm and in cardiogenesis [34]. BMP-2 has a prominent role during epithelial-mesenchymal transition (EMT) and formation of myocardial cells to ensure proper heart development [6,23,71]. BMP-2 KOs in mice led to malformation of the heart, heart valves, and irregular myocardial patterning that resulted in lethality during early embryonic stages $[23,24,26,34,35]$. Further, BMP-2-deficient mice exhibited malformation of both the chorion and amnion, suggesting BMP-2's diverse role in many cardiac developmental processes [35,72-74]. While assisting in the cardiogenesis, BMP-2 is also involved in the formation of the pulmonary system. For example, when the lung begins to develop in early embryonic stages, BMP-2 activates BMP-signaling pathways and stimulates formation of alveolar cells and regulates pulmonary remodeling [75-77]. BMP-2 also regulates pulmonary specification and branching to increase alveolar surface area [76,77]. Lastly, BMP-2 is required for proper osteogenesis, chondrogenesis, and adipogenesis during development $[2,16,18,78]$. BMP-2 is the ligand needed to activate the Smad and Non-Smad pathways that lead to bone, cartilage, and fat development; KOs or under-expression of BMP-2 result in the inability of these cells and tissues to form $[18,32,79,80]$. Thus, BMP-2 has a prominent role in many stages of development and demonstrates its multi-functionality.

\subsection{BMP-2 Receptors and Expression}

Over the past decades, researchers discovered several mutations within the BMP-2 gene, revealing the importance of BMP-2 in regulating bone homeostasis and survivability. For example, mutations in the $B M P-2$ gene can cause altered signaling leading to brachydactyly and lethality, as downstream effector proteins and signaling pathways are not effectively activated [34,81-83]. In order for BMP-2 to elicit its many cellular responses, it must bind to specific receptors and activate a signaling cascade. However, before investigating the functional role of BMP-2, we first must investigate how BMP-2 becomes functional (or how it is transcribed and translated). Once the BMP-2 gene is transcribed and translated, BMP-2 is not yet functional. To become active, the newly formed preproprotein undergoes proteolytic cleavage by proprotein convertase subtilisin/kexin type 5 (PCSK5) at the C-terminus [84]. The functionally cleaved 115 amino acids (AA) BMP-2 protein is secreted from the cell to serve as an autocrine or paracrine factor, binding to receptors on both osteoblasts and osteoclasts $[46,47,85]$. Once released into the bone matrix or blood, BMP-2 can be processed further by proteases. Specifically, these proteases located in the serum are able to cleave BMP-2, 4, and 7, which can de-differentiate newt muscle cells and allow them to re-enter the cell cycle. Here, the de-differentiated cells are able to commit to other cell fates, dependent on which factors they are exposed to [86,87]. Further studies elucidating this mechanism in other animals should be explored.

BMP-2 binding to BMP type I and type II serine/threonine kinase receptors leads to activation of several downstream signaling pathways along with upregulation of the BMP-2 gene. Cells can express various types of receptors located on the cell surface. BMP-2 can bind to BMP receptor type Ia (BMPRIa), BMP receptor type Ib (BMPRIb), and activin receptor type Ia [88,89]. BMPRIa is located on most cell surfaces while BMPRIb is less common [90-92]. BMP-2 preferentially binds 
to preformed BMPRII-BMPRIa/b complexes or binds to BMPRIa specifically at its beta4beta5 loop, which can then oligomerize with BMPRII [93,94]. Additionally, BMPRII can also oligomerize with BMPRIa/b alone when BMP-2 binds, which causes the type I receptors to oligomerize with the type II receptors and activates different signaling pathways [95]. BMPRs are known to be expressed on both osteoblasts and osteoclasts, which is critical for bone remodeling and homeostasis. On these cells, BMP receptor signaling is also regulated by the localization of receptors in specific membrane domains. Receptors can be localized in caveolae, clathrin coated pits (CCPs), and lipid rafts located on the plasma membrane [96-100]. Their localization can determine which signaling pathways are activated $[96,97,99,101]$. Because BMPRs regulate many pathways, mutations can be detrimental. For example, in early stages of development, most gene mutations within the BMPRIa gene result in a shorter protein sequence, which leads to inadequate BMP signaling as the specific ligands are unable to bind to BMPRs [102-107]. BMPRIa has about 60 known mutations that cause juvenile polyposis syndrome, which can lead to unregulated cell growth and causes ectopic polyp formation [102-107]. Additionally, BMP-2 can bind to three type II receptors, including BMP receptor type II (BMPRII), activin receptor type IIa (ActRIIa), and activin receptor type IIb $[1,108]$. BMP-2 binds to BMPRIa with the highest affinity $[94,109]$.

Once BMP-2 binds to the BMPRs, phosphorylation of BMPRIa by BMPRII leads to adipogenesis, chondrogenesis, and osteogenesis, whereas phosphorylation of BMPRIb leads to apoptosis and cell death $[28,34,95,110-112]$. Further, different patterns of receptor oligomerization determine the downstream pathways BMP-2 activates. For example, Smad signaling is activated when BMP-2 binds to preformed heteromeric complexes, whereas Non-Smad signaling (such as ERK) is activated when BMP-2 binds to BMPRIa and BMPRII is recruited after $[18,19,109]$. Therefore, localization and oligomerization of BMPRs will determine the signaling response after BMP-2 binds. [16,17,113-115].

In addition to BMPRs, there are co-receptors, such as BMP and activin membrane-bound inhibitor (BAMBI), Dragon, endoglin, and betaglycan that can be associated with BMPRIa, which can enhance or inhibit BMP-signaling [112]. For example, BAMBI is a pseudoreceptor localized near BMPRs. When BMP-2 binds, the BMPRs activate BAMBI, and BAMBI decreases the BMP-signaling response as a negative regulator [116-118]. Additionally, DRAGON enhances BMP-signaling during development, especially in the nervous system [119-121]. Endoglin, a type 1 transmembrane glycoprotein, is a co-receptor of BMPRII and is crucial for cardiogenesis and angiogenesis, along with influencing Non-Smad signaling by affecting cell growth and adhesion [122-124]. Betaglycan is a commonly expressed proteoglycan that serves as a co-receptor to BMPRII. One of its functions is to negatively regulate BMP-signaling by activating inhibin, which then associates with the receptor and prevents BMP-2 binding [125-128]. Along with these co-receptors and associated proteins, previous studies have demonstrated a Heparin-binding site on BMP-2 that regulates its activity [129-132]. This Heparin-binding site regulates BMP-2's activity as when it travels through the ECM of cells, it binds to ECM proteins, such as fibronectin and tenascin C [133-135]. This binding limits the migration and movement patterns of BMP-2, limiting its bioavailability and activity throughout the body, which may be useful when sustaining delivery of rhBMP-2 in clinical applications [136,137]. This is further demonstrated as when this binding site is mutated, BMP-2 activity increased [129,138]. This extensive regulation of BMP-2 is a combination of negative feedback, co-receptors/proteins, and binding domains.

Further, studies have demonstrated that BMP- 2 is expressed in a variety of cells. By being expressed largely throughout the body, BMP-2 is able to effectively function and activate the many signaling pathways listed above. For example, BMP-2 is expressed in many tissues, including the liver and the lungs, as well as in bone (primarily in osteoblasts and osteocytes) [37,139]. Additionally, BMP-2 can be paracrine or autocrine, acting as a local or systemic factor to initiate cell-to-cell responses or travelling through the serum to target cells [140-142]. Further, in the absence of BMP-4, BMP-2 has been shown to compensate for its functions, especially in chondrocytes, bone, and during development [32,143]. 
These expression patterns are vital to ensure proper maintenance of alveolar tissue, hepatocytes, developmental processes, and bone homeostasis.

\subsection{BMP-2 Structure and Receptor Binding}

BMP-2 was first discovered in 1965 due to its potent osteo and chondro-inductive abilities; however, the structure of BMP-2 was not crystallized until 1999. After BMP-2 was synthesized as a 453 residue proprotein, it became glycosylated and further proteolytically cleaved and dimerized. This yields the final, mature disulfide linked homodimer. Each respective monomer is 114 residues in length. A 3D rendering of the dimer's crystallized structure revealed that the biologically active

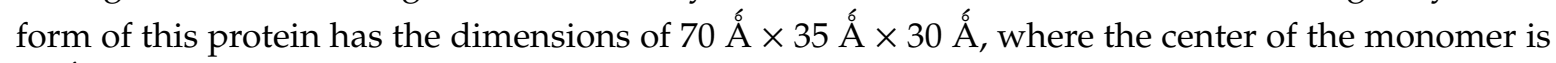
10 Á thick. Each individual monomer contains a cystine-knot formed through six cysteine residues creating three intrachain disulfide bridges. This structure is critical for BMP-2, as this provides stability that would otherwise be lacking due to the lack of a hydrophobic core. However, this is shortly resolved once the two monomers form the dimer, further stabilizing the structure of BMP-2, as well as creating extra stability through the creation of a hydrophobic core between the two monomers. The folding topography of BMP-2 features the key components of other TGF- $\beta$ superfamily proteins. Briefly, they consist of two separated antiparallel $\beta$-sheets, which is made up of nine $\beta$ strands. The strands do not form four antiparallel $\beta$ sheets because they too far apart to participate in hydrogen bonding. The second sheet adopts a twisted crossover confirmation. There is also a four-turn $\alpha$-helix which is located perpendicular to the $\beta$ strands [144].

BMP-2, like BMP-4, can exist in a soluble form so that it can be easily transported. When BMP-2 is in its soluble form, it binds to a lower affinity to its type II receptor, BMPRII $[145,146]$. However, in most cases, BMP-2 preferentially binds to the type I receptors, most notably BMPRIa [21,147]. In order to determine exactly how BMP-2 and BMPRIa binding is achieved and facilitated, the bound crystal structure needed to be resolved. Once crystallized, it was found that BMP-2 bound to BMPRIa through the figure-helix groove of the BMP-2 dimer. It is bound in such a way that both monomers of BMP-2 come into contact with the receptor and the C-terminus of the receptor chains are found $65 \AA$ Apart. The general structure of BMPRIa can be likened to a left hand where the thumb is the helix backbone, the three extended middle fingers are the central beta sheet, and the small or pinky finger is slightly bent, indicating a loop between the $\beta 1-\beta 2$ sheets. In 2001, two binding epitopes on BMP-2 were discovered, known as the "wrist" and "knuckle" epitopes. The wrist epitope encompasses a larger area, correlating with high affinity to BMPRIa binding, while the knuckle epitope encompasses a smaller area that has low affinity for BMPRII binding. This is because binding residues located within the knuckle epitope are found in only one BMP-2 monomer, while binding residues in the wrist epitope are found in both monomers. Interestingly, the distances between the wrist and knuckle epitopes is 10-15 Á, but the distances between the two receptors are much larger: 40-55 Á. This distance between the two receptors helps to further stabilize the overall bound structure of BMP2 and its receptors [148].

There are several regulatory feedback mechanisms which help to control BMP-2 induced activity. One of these mechanisms is through BMP antagonists, like Noggin. It was discovered that the structure and complex of Noggin inhibited BMP signaling by directly binding and blocking critical epitopes on both the type I and type II receptors. Noggin is a twelve-membered cysteine knot protein; therefore, it can mimic those wrist and knuckle epitopes that BMP-2 contains, in order to facilitate competitive binding to the BMP receptors, thus inhibiting BMP-2 induced signaling [149]. This means both the location and proximity of the receptors is critical for proper BMP-2 binding and subsequent pathway activation [148].

\subsection{BMP-2 Signaling Pathways}

Many important signaling pathways for osteogenesis, cell survival, and apoptosis are activated by BMP-2 $[20,22,28,41,150]$. Once BMP-2 binds to BMPRs, it activates Smad and Non-Smad signaling 
pathways (Figure 3). The Smad pathway is activated when BMPRIa and BMPRIb phosphorylate downstream proteins, namely Smad1/5/8 [109]. The phosphorylated Smads recruit Smad4, and the complex translocates into the nucleus and acts as a transcription factor for genes, such as RUNX2 and $O s x[15,151]$. Additionally, in specific circumstances, BMP-2 can also activate Smad2/3 signaling through BMPRIa. In fact, Smad2/3 was preferentially activated in embryonic and transformed cells, suggesting the promiscuity of BMP-2 to regulate developmental processes and cell division [152-154]. However, this process is not fully understood and BMP-2 may also exert this response in other cells. Thus, future studies should explore this area to delineate more of BMP-2's actions and current information about the promiscuity of BMP-2 can be found in a review article by Nickel and Mueller [155].

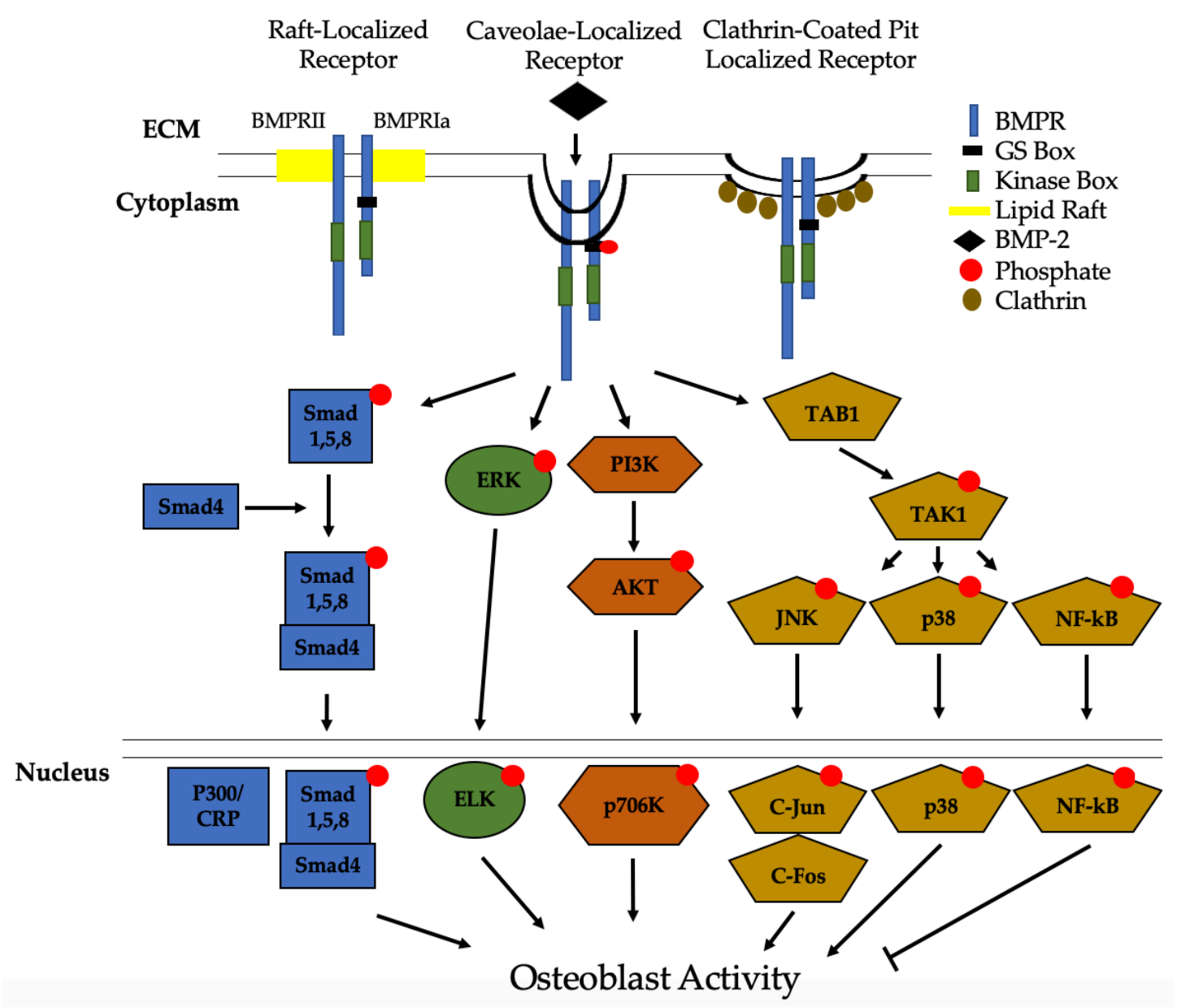

Figure 3. Bone Morphogenic Protein 2 (BMP-2) activation of signaling pathways. Once BMP-2 binds to the BMPRs located in lipid rafts, caveolae, and clathrin coated pits (CCPs), constitutively active BMPRII phosphorylates BMPRIa. This leads to downstream activation of the Smad pathway or the non-Smad pathways. In non-Smad signaling, the extracellular signal-related kinase (ERK), phosphatidylinositol 3 -kinase (PI3K), and the transforming growth factor- $\beta$-activated kinase $1 /$ binding protein 1 (TAB1/TAK1) pathways are activated. All of these pathways, except for NF-kB, lead to an increased differentiation of MSCs and osteoprogenitors into osteoblasts.

Recently, we identified Casein Kinase 2 (CK2) as a key regulator of the BMP-signaling pathway [156]. Without the BMP-2 ligand present, CK2 is bound to BMPRIa, preventing the activation of downstream effector proteins. However, when BMP-2 is bound, CK2 is released and an upregulation of osteogenesis is observed [156-158]. In the non-Smad pathway, MAPK signaling activates extracellular signal-regulated kinase (ERK), phosphatidylinositol-2 kinase (PI3K), and the TAB1/TAK1 pathways [31,156-159]. Each of these signaling events, except for TAB1/TAK1 which activates NF-kB and p38, leads to differentiation 
of osteoblast precursors into osteoblasts. NF-kB has been shown to inhibit osteoblast function in osteoporotic mice models and requires further investigation [160,161]. Other pathways that can be activated by BMP-2 to differentiate myoblasts and other pre-osteoblasts into osteoblasts include EIF2AK3-EIF2A-ATF4 and RhoA/Rb [162-164].

As mentioned previously, BMPR localization on the plasma membrane determines endocytosis and which signaling pathways are activated. Previous studies first demonstrated that BMPRs were predominantly localized to CCPs [97]. However, subsequent research indicated that BMPRs also localize to caveolae, and that caveolae are essential regulators of Smad-signaling pathways [96]. Data demonstrated that BMP-2 preferentially binds to BMPRIa aggregates in caveolae with a higher force and frequency than CCPs to activate Smad signaling pathways [96,99,101,114,165]. Although BMPRs are primarily found in caveolae or CCPs, they can also localize on lipid rafts $[97,98,114]$. Additionally, BMP-2 has been shown to activate the Wnt signaling pathway; however, the proteins involved and whether BMP-2 induces the Wnt/ $\beta$-Catenin pathway, or vice-versa, are still unknown $[157,166,167]$.

\subsection{Intracellular and Extracellular Regulation of BMP-2}

Signaling cascades for any cellular pathway must be regulated, and BMP-2 signaling is no different, especially due to the multiple signaling pathways activated by BMP-2. Various proteins have been identified to regulate this response. The activity of BMP-2 is enhanced or inhibited intracellularly and extracellularly. For instance, the genes Twisted gastrulation (Tsg) and Shrew promote BMP-2 activity and enhance its activity [168-170]. Further, BMP-2 is regulated intracellularly and extracellularly by several secreted antagonists. Factors such as noggin, sclerostin (SOST), and follistatin directly bind to BMP-2 in the ECM to prevent its interaction with BMPRs, especially during development [171-173]. Specifically, other ECM proteins, including fibronectin, fibrinogen, and tenascin C, are able to bind to the Heparin domains of BMP-2, regulating its activity and migration [130,133,135,174-176]. Additionally, chordin is a protein secreted from bone cells in the spine that can directly bind to BMP-2 and prevent its interaction with BMPRs [170,171,177]. Intracellularly, inhibitory Smads (I-Smads) 6 and 7 directly regulate Smad signaling induced by BMP-2, usually by preventing downstream signaling cascades [178]. Despite these multiple regulations, abnormal bone and cartilage loss still occurs in osteoporotic and osteoarthritic patients. The underlying mechanisms are an active area of present research, but it is hypothesized that osteoporotic patient osteoblasts have irregular BMPRIa function, leading to dysregulation of BMPR trafficking and bone homeostasis [179]. The current identified agonists and antagonists of BMP-2 that may be involved are summarized in Table 1. Furthermore, we also include known associated proteins with BMPRs that limit the activity of BMP-2 in Table 2.

\subsection{Regulation of the BMP-2 Signaling Pathway by Casein Kinase 2 (CK2)}

Recently, CK2 was not only identified as a key regulator of the BMP-2 pathway, but also as an inhibitor of this pathway. When inhibiting this pathway, CK2 is bound to three phosphorylation sites of BMPRIa, preventing the activation of downstream proteins [156]. To observe the interaction of BMPRIa and CK2, we constructed mutants of BMPRIa for each phosphorylation site at specific amino acids (AA 213-217; AA 324-238; AA 475-479) were constructed [157]. The BMPRIa mutants led to increased adipogenesis, osteogenesis, and chondrogenesis by preventing the binding of CK2 [158]. Additionally, to understand the relation between CK2 and BMPRIa, our lab deleted the BMPRIa gene in mice and surprisingly, this led to increased bone formation $[180,181]$. Next, the Nohe lab designed peptides mimicking the three phosphorylation sites for BMPRIa were constructed and named CK2.1, CK2.2, and CK2.3. These peptides were able to bind and prevent CK2 from interacting with BMPRIa, leading to increased adipogenesis, osteogenesis, and chondrogenesis, similar to the BMPRIa mutants [31,115,156,157,182,183]. Additionally, overexpression of a BMPRIa mutant (SLKD) that lacked a serine AA to prevent binding of CK2 led to increased mineralization via extracellular signal-related kinase/,itogen-activated protein kinase kinase (ERK/MEK) signaling, indicating that the 
BMP-2 signaling pathway is regulated by CK2 $[157,158]$. This suggests that exogenous BMP-2 is not needed to activate downstream pathways if CK2 inhibitors are present.

Table 1. Known agonists and antagonists of BMP-2.

\begin{tabular}{|c|c|c|c|}
\hline Protein/Gene & Type of Protein & Function & References \\
\hline Brorin & Glycoprotein & Inhibits BMP-2 activity & [184-186] \\
\hline Cerberus & Cytokine & Blocks BMP-2 signaling & {$[187,188]$} \\
\hline Chordin & Glycoprotein & $\begin{array}{l}\text { Binds directly to BMP-2 to } \\
\text { prevent its activity }\end{array}$ & {$[170,171,177,189,190]$} \\
\hline DAN Family & Glycoproteins & $\begin{array}{l}\text { Binds directly to BMP-2 } \\
\text { and inhibits its activity }\end{array}$ & [191] \\
\hline Follistatin & Glycoprotein & $\begin{array}{l}\text { Binds directly to BMP-2 to } \\
\text { prevent its activity }\end{array}$ & {$[173,192-194]$} \\
\hline FLRG & Glycoprotein & $\begin{array}{l}\text { Downregulates BMP-2 and } \\
\text { limits its activity }\end{array}$ & [194-196] \\
\hline Grem2 & Glycoprotein & Inhibits BMP-2 activity & {$[197,198]$} \\
\hline Noggin & Glycoprotein & $\begin{array}{l}\text { Binds directly to BMP-2 to } \\
\text { prevent its activity }\end{array}$ & {$[9,172,199,200]$} \\
\hline Sclerostin (SOST) & Glycoprotein & $\begin{array}{l}\text { Binds to LRP5/6 to prevent } \\
\text { Wnt and BMP-2 signaling }\end{array}$ & [201-204] \\
\hline Shrew & Shrew-1: Transmembrane protein & $\begin{array}{l}\text { Enhances peak BMP-2 } \\
\text { signaling activity }\end{array}$ & {$[169,170]$} \\
\hline Twisted Gastrulation & Produces small cysteine rich protein & $\begin{array}{l}\text { Can enhance or inhibit } \\
\text { BMP-2 activity }\end{array}$ & {$[169,205-210]$} \\
\hline USAG-1 & Glycoprotein & $\begin{array}{l}\text { Physically interacts with } \\
\text { BMP-2 to prevent signaling }\end{array}$ & {$[211,212]$} \\
\hline
\end{tabular}

\subsection{Endocytosis and Degradation of BMP-2 and BMPRs}

As stated in previous sections, BMP-2-BMPR complexes can be endocytosed into cells via CCPs, caveolae, or lipid rafts. However, upon endocytosis, the complex continues as a signaling endosome, and is degraded (or recycled) to the plasma membrane [213]. First, to regulate the signaling activity of BMP-2 after endocytosis, this protein must be deactivated or degraded to prevent continuous expression. To suppress BMP-2 activity, data demonstrated that BMP-2 is ubiquitinated at several lysine residues, initiating its degradation [214]. Further, if this proteasomal-ubiquitination pathway is inhibited, BMP-2 activity is increased, and the protein is secreted more rapidly from cells [214,215]. However, the time-course of BMP-2 degradation and the mechanism of BMP-2 recycling remains unknown and requires further research.

For BMPRs, previous studies demonstrate that BMPRII and BMPRIa are regulated by Dullard, which is a phosphatase, upon endocytosis. When Dullard is inhibited, BMP signaling is enhanced, and when Dullard is active, BMPRIa and BMPRII are deactivated and dephosphorylated to inhibit BMP signaling $[150,216,217]$. Additionally, once the BMPRs are endocytosed, a ubiquitin ligase named Smurf1 was also identified to ubiquitinate the BMPR complexes and cause degradation [218-221]. Together, these proteins regulate BMP-2/BMPR activity intracellularly. 
Table 2. Known proteins associated with BMPRs.

\begin{tabular}{lc}
\hline \multicolumn{1}{c}{ Protein } & References \\
\hline FGFR substrate & {$[222]$} \\
PKC $\beta$ & {$[222]$} \\
Rab geranylgeranyl transferase & {$[222]$} \\
MOS & {$[222]$} \\
MAPKKK8 & {$[222]$} \\
CtBP & {$[222]$} \\
Forkhead L1 TF & {$[222]$} \\
LIM hd 1 & {$[222]$} \\
p50b & {$[222]$} \\
SemF & {$[222]$} \\
hnRNP R & {$[222]$} \\
Neurobeachin & {$[222]$} \\
Tubulin $\beta 5$ & {$[222]$} \\
Onconin-90 & {$[222]$} \\
ARP8 & {$[222]$} \\
Arylsulfotransferase & {$[222]$} \\
Carboxylesterase 3 & {$[222]$} \\
Contrapsin & {$[222]$} \\
Protein tyrosine kinase 9 & {$[222]$} \\
C4b-binding protein & {$[222]$} \\
\hline
\end{tabular}

\section{Clinical Applications and Limitations of BMP-2}

In 2002, the FDA approved clinical use of rhBMP-2, and it remains the only commercially available therapeutic that serves as an alternative to bone grafts [223]. Additionally, rhBMP-2 is available as a therapeutic in anterior lumbar interbody fusion during spinal fusions within tapered cages [49-51]. rhBMP-2 has also been used during cranioplasty, especially following maxillofacial injury, to induce osteogenesis [224]. Because of the promising and well-known osteogenic potential of rhBMP-2, this therapeutic also seems ideal for osteoporotic and osteoarthritic patients. In addition, it has been postulated that BMP-2 may be used to treat disorders such as multiple sclerosis, cardiovascular disease, anemia, atherosclerosis, renal calcification, and kidney failure [121,134,197,225-230]. However, over the past decade, several complications and side-effects have been identified after using rhBMP-2, potentially indicating that it is unsafe for bone fractures and other diseases [223].

Because BMP-2 is a vital and critical growth factor and holds clinical applications, it became a popular protein studied in the clinical research field. Additionally, studies demonstrated that BMPs themselves have been implicated in both tumor progression and suppression. BMP-2 specifically has been implicated in suppressing tumor development in human colorectal cancer cells [231]. However, it has also been implicated in tumor progression through stimulating epithelial to mesenchymal transition (EMT) and breast cancer stemness through Rb and CD44 [164]. In fact, low levels of BMP-2 have been implicated in poor patient prognosis in prostate cancer [232]. Due to these varying reports, it is suggested that use of BMP-2 in the clinic in cancer patients should be carefully considered [233].

BMP-2 was introduced into the clinic because of complications surrounding complex bone healing fractures, or delayed bone healing. At the time rhBMP-2 delivery, known as INFUSE (Infuse bone graft, lumbar tapered device), was with a bovine collagen matrix soaked in BMP-2 [223]. As stated previously, INFUSE has been associated with a variety of negative effects, which greatly limits its use in the clinic. This could be due to the amount of BMP-2 used for these procedures, especially in spinal fusion. Normally, there are $2 \mathrm{mg}$ of BMP-2 in circulation and use in the human body. INFUSE uses $40 \mathrm{mg}$ of BMP-2 in order to promote its positive osteogenic effects [224,225]. However, the amount of BMP-2 used causes life-threatening complications through swelling in the neck. It was also discovered that only 75 ug of BMP-2 remained bound to collagen within the tapered cages, while the remaining amounts of BMP-2 precipitated onto the bovine cages, thus causing significant inflammation, swelling, 
and heterotrophic ossification [226,227]. Further elaborating on this administering technique, it has been demonstrated that Noggin is upregulated after BMP-2 is injected [234,235].This poses serious complications because Noggin negatively regulates BMP-2 and can prevent BMP-2's course of action. Therefore, high concentrations of BMP-2 are needed to overcompensate, which leads to a variety of complications and side-effects. Additionally, therapeutics targeting Noggin has been ineffective, as Noggin can be resistant or insensitive to these treatments [236].

It has been hypothesized that the supraphysiological amounts of BMP-2 used in INFUSE cause the major adverse reactions. Therefore, limiting the amount of BMP-2 or creating slow-release vehicle delivery systems is of active research interest. There are several types of rhBMP-2 delivery systems: binding BMP-2 to a molecular vehicle through intermolecular forces, encapsulating or absorbed BMP-2, coupling by affinity interactions, non-site directed covalent coupling, or site-directed covalent coupling [237]. Many research groups prefer the non-covalent coupling of BMP-2 to a delivery vehicle, as covalent attachment of BMP-2 could affect its overall activity and later associations. INFUSE used collagen sponges, which are the most widely studied and characterized rhBMP-2 delivery systems. However, a major disadvantage to this medium is that it relies on an early burst-release of BMP-2 [238]. Other labs are working on other types of delivery vehicles, in order to provide a slow release system for BMP-2 within the body [237].

Recent data have shown that cells extracted from patients diagnosed with osteoporosis do not respond to BMP-2 stimulation, whereas cells extracted from patients diagnosed with osteoarthritis are still responsive [179]. This demonstrates that BMP-2 cannot enhance bone mineral density in patients diagnosed with osteoporosis, but still causes adverse side-effects such as radiculitis, hematoma, and an increased rate of microfractures [48]. As a result, BMP-2 may not be useful for treating osteoporosis, and alternative therapeutics are desperately needed (described in the next section).

In addition to osteoporotic patients' unresponsiveness to BMP-2, rhBMP-2 injections also lead to an increased rate of osteolysis and microfractures [48]. Recently, clinical evidence demonstrated that after lumbar spinal fusion with rhBMP-2 injection in titanium tapered cages, at least three or more patients were diagnosed with osteolysis several months later $[55,56,239]$. Along with an increased bone resorption rate, an increased occurrence of radiculitis and nerve injury was also present after usage of rhBMP-2 [48,53,240-242]. Another major side-effect of using rhBMP-2 is ectopic bone formation, due to BMP-2 leaking out of the implant site. In fact, $70.1 \%$ of patients administered rhBMP-2 showed ectopic bone formation on a CT scan $[223,243]$. The quality of bone formed after rhBMP-2 use comes into question, as an increased risk of bone cyst formation was also observed. BMP-2 itself is an important growth factor for adipocytes (fat cells) in addition to osteoblasts; therefore when rhBMP-2 is administered, MSCs can be terminally differentiated into either osteoblasts or adipocytes, causing more lipid formation within the newly formed bone. While bone volume may be increased with the use of rhBMP-2, trabecular spacing is decreased and lipid deposition is increased, decreasing the overall quality of the bone $[244,245]$. Further, retrograde ejaculation was a common diagnosis after patients were injected with rhBMP-2 [246,247]. A significant black box warning was issued by the FDA in 2008 regarding the use of rhBMP-2, stating that there had been an increase in local inflammation responses causing cervical spinal swelling and death [248]. Therefore, with all these adverse complications, rhBMP-2 may not be suitable as a bone therapeutic. Current research is attempting to develop fluorescent BMP-2 analogs to elucidate the lack of responsiveness to rhBMP-2 $[249,250]$.

\section{Alternative Therapeutics to BMP-2}

Currently, osteoporosis and lone bone mineral density affects 54 million Americans (NOF, 2020). A commonly used treatment is the Human Parathyroid Hormone (Teriparatide [PTH 1-30]) therapy, which helps to control calcium homeostasis and has increased bone mineral density and trabecular bone mass [251-253]. Teriparatide is a peptide hormone that targets G-Protein-Coupled-Receptors and stimulates an increase of adenylate cyclase, which results in an increase in calcium that is then used to promote bone growth [254]. Teriparatide is classified as an anabolic drug and is intermittently injected 
subcutaneously [255]. When a patient stops receiving Teriparatide injections, bone mineral density decreases. However, bisphosphonates can then be provided to restore bone loss by inhibiting the activity of osteoclasts, which helps to preserve the newly formed bone [256-258]. Bisphosphonates can also be used without Teriparatide, as they are analogs of pyrophosphates and bind to hydroxyapatite to prevent bone resorption [257]. Use of these treatments can lead to hypercalcemia, increased risk of developing tumors, and kidney disorders [259]. Although Teriparatide and bisphosphonates increase bone mineral density and limit osteoclast activity, patients are still at risk of developing future complications.

In addition, there are other current treatments that also target osteoclast activity and serve as antiresorptive drugs. For example, hormone replacement therapy, such as Selective Estrogen Receptor Modulator (SERM), was developed for post-menopausal women. Although this therapeutic replaces decreased estrogen, several side-effects have been noted. These include hot flashes, cramps, and a variety of thromboses and embolisms [252,260-264]. Another treatment is Denosumab, which binds to RANK-L to prevent activation of osteoclasts. Although this therapeutic has successfully decreased osteoclast activity and prevented fractures, it has led to side-effects, such as hypocalcemia, jaw osteonecrosis, and tumor progression [265-267].

Romosozumab was recently approved as an osteoporotic treatment in 2019. This drug has demonstrated a decrease in bone resorption while increasing bone formation [268]. It functions by binding directly to SOST, which is a BMP-antagonist that prevents activation of Smad-signaling by binding to the low-density lipoprotein-related protein (LRP5) receptor, thereby preventing activation of the $\beta$-Catenin/Wnt/BMP-signaling pathways and osteogenic genes [204,269]. To date, Romosozumab has decreased the occurrence of spinal injuries, but there have been two reported cases of jaw osteonecrosis and one case of hepatitis [268,270]. Due to the novelty of this drug, other benefits and side-effects remain unknown.

A novel peptide named Casen Kinase 2.3 (CK2.3) was manufactured and developed by our lab to specifically bind CK2 and prevent its association with BMPRIa. With CK2.3, the BMP-signaling pathway is activated without exogenous BMP-2 by blocking CK2 binding and activating downstream signaling pathways. CK2.3 has successfully activated downstream effector proteins, such as Smad1/5/8, pERK, and Akt [31]. Further, CK2.3 is able to enter the cell, primarily through caveolae, indicating that it is biologically active [271]. The biological activity of CK2.3 was also demonstrated as the peptide induced trabecular bone formation and bone mineralization while limiting osteoclastogenesis, indicating its potential use as an osteoporotic therapeutic [31,179,182,183]. However, the trafficking of CK2.3 and its precise course of action within osteoblastogenesis and osteoclastogenesis are still unknown and are current research topics. Another CK2 inhibitor, namely CX-4945, inhibits CK2/Akt signaling and decreases osteoclast formation and activity [272-274]. CX-4945 is currently in clinical trial phases and requires further testing before being administered as a treatment. The current available treatments stated above along with their additional side-effects are summarized in Table 3.

Another important area of research is the usage of BMP-2 mimetic peptides to induce bone formation and Smad signaling. These peptides are of importance because they currently exert osteoinductive properties but are not commercially available therapeutics. One of these peptides is P17-BMP-2. P17-BMP-2 enhanced bone repair after injury, as well as stimulating an increase in osteoblast differentiation and bone regeneration $[275,276]$. Additionally, other mimetic peptides including P20 and P24 have demonstrated osteogenic properties and the ability to differentiate MSCs into osteoblasts; thus, these peptides have the potential to be used in bone repair and/or regeneration, but require further study and experimentation [275-279]. 
Table 3. Current osteoporosis treatments, function of the drugs/treatments, and the drug/treatment side-effects.

\begin{tabular}{|c|c|c|c|}
\hline Drug/Treatment & $\begin{array}{l}\text { Drug/Treatment } \\
\text { Function }\end{array}$ & Side-Effects of Drug/Treatment & References \\
\hline Bisphosphonates & Antiresorptive & $\begin{array}{l}\text { Gastrointestinal discomfort; hypocalcemia; } \\
\text { esophageal cancer; jaw osteonecrosis; } \\
\text { decreased bone turnover rate }\end{array}$ & {$[252,253,257-259,280-294]$} \\
\hline Calcitonin & Antiresorptive & $\begin{array}{l}\text { Nausea; increased risk for cancer; allergic } \\
\text { reactions; hypocalcemia }\end{array}$ & {$[41,295]$} \\
\hline Denosumab & Antiresorptive & $\begin{array}{l}\text { Tumor progression; hypocalcemia; jaw } \\
\text { osteonecrosis; pancreatitis }\end{array}$ & [265-267] \\
\hline $\begin{array}{l}\text { Hormone replacement } \\
\text { therapy (i.e., selective } \\
\text { estrogen receptor } \\
\text { modulator [SERM]) }\end{array}$ & Antiresorptive & $\begin{array}{l}\text { Hot flashes; leg cramps; pulmonary } \\
\text { embolism; deep vein thrombosis; retinal } \\
\text { vein thrombosis; thromboembolism; } \\
\text { invasive breast cancer }\end{array}$ & {$[260-264,296]$} \\
\hline Romosozumab & $\begin{array}{l}\text { Antiresorptive and } \\
\text { Anabolic }\end{array}$ & $\begin{array}{l}\text { Jaw osteonecrosis; hepatitis; } \\
\text { nasopharyngitis; hypercalcemia; arthralgia }\end{array}$ & {$[268,270,297-300]$} \\
\hline Teriparatide (PTH 1-34) & Anabolic & $\begin{array}{l}\text { Nausea; vomiting; headaches; } \\
\text { hypercalcemia; hypercalciuria; } \\
\text { hypomagnesemia }\end{array}$ & {$[252,253,301-305]$} \\
\hline
\end{tabular}

\section{Conclusions}

BMP-2 is a powerful player in all organs. Potential treatments for osteoporosis, osteopenia, osteoarthritis, and coronary artery disease with BMP-2 and/or its signaling pathways are in development. However, to date, the FDA has only approved BMP-2 during anterior lumbar interbody spinal fusions, cranioplasties, and maxillary facial reconstructive surgery. Therefore, the bone and skeletal disorders were the main focus of this review.

During development, BMP-2 promotes cardiogenesis, neurogenesis, development of the ocular system, and development of the $\mathrm{D} / \mathrm{V}$ and $\mathrm{A} / \mathrm{P}$ axes. BMP-2 deficiency during development ultimately leads to embryonic or post-natal lethality due to its diverse functions. In addition, over-expression of BMP-2 can lead to myopia or neural tube closure defects. Therefore, its activity is tightly regulated throughout embryogenesis, development, and adulthood. Further into adulthood, BMP-2 is responsible for inducing endochondral and intramembranous ossification, activation of the adipogenic and chondrogenic signaling pathways, and maintenance of neurons, lungs, and cardiac tissue. Because of its versatile functions, BMP-2 has been used as an osteoinductive agent. However, evidence during the past decade has demonstrated adverse side-effects of BMP-2, such as hematoma formation, osteolysis, increased spontaneous fractures, coronary artery disease, myopia, and other complications. Other methods to induce osteogenesis, such as PTH therapies, bisphosphonates, and Romosozumab have been implemented, but they also pose side-effects, such as tumor growth, hypercalcemia, and jaw osteonecrosis. Synthesized peptides, such as Romosozumab and CK2.3, promote osteoblastogenesis and limit osteoclastogenesis, making them possible therapeutics for osteoporosis by BMP-signaling without exogenous BMP-2 (Figure 4). Additionally, other small peptides, such as Dorsomorphin (DMH1), can target BMPRIa to inhibit BMP-signaling. Inhibition of this pathway leads to decreased calcium release, reduced medial arterial calcification, and decreased metastasis in breast cancer [306-308]. With these applications, the BMP-signaling pathway can be implicated to treat a variety of diseases. However, the complete functions and side-effects of these peptides are still unknown. With millions of Americans diagnosed with osteoporosis, cardiovascular disease, and cancer, there is a desperate need for novel therapeutics that can utilize the BMP-signaling pathway to treat these disorders with no adverse side-effects. 
A

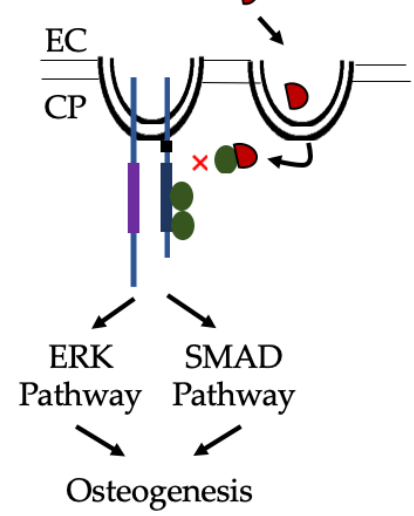

B

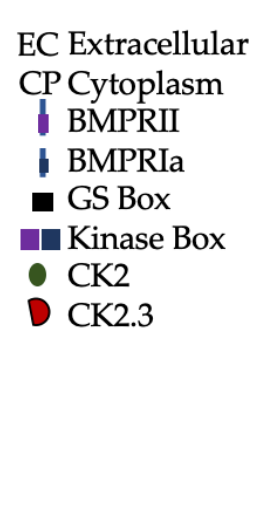

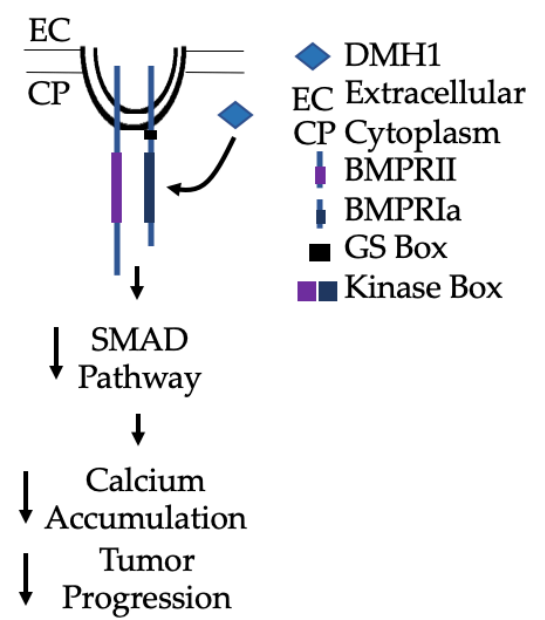

Figure 4. Activation and inactivation of Smad signaling without exogenous BMP-2. (A) CK2.3 is endocytosed into cells via caveolae, and then binds to CK2 to prevent its association with BMPRIa. This results in activation of Smad and non-Smad signaling pathways (such as ERK), leading to osteogenesis. (B) Alternatively, BMPRIa inhibitors, such as Dorsomorphin (DMH1), specifically bind to the receptor and inhibit Smad-signaling to limit arterial calcification by limiting $\mathrm{Ca}^{2+}$ accumulation. Further, DMH1 has been implicated in slowing tumor progression and metastasis.

Author Contributions: Conceptualization, D.H., H.W.D., and A.N.; methodology, D.H. and A.N.; software, D.H.; validation, D.H., H.W.D. and A.N.; formal analysis, D.H.; investigation, D.H. and H.W.D.; resources, A.N.; data curation, D.H.; writing—original draft preparation, D.H.; writing—review and editing, D.H., H.W.D., and A.N.; visualization, D.H.; supervision, A.N.; project administration, A.N. All authors have read and agreed to the published version of the manuscript.

Funding: This research received no external funding.

Acknowledgments: The authors would like to acknowledge John Nguyen, Brian Heubel, and Ryan Wood for the assistance with manuscript editing and alterations.

Conflicts of Interest: The authors declare no conflict of interest.

\section{References}

1. Bragdon, B.; Moseychuk, O.; Saldanha, S.; King, D.; Julian, J.; Nohe, A. Bone Morphogenetic Proteins: A critical review. Cell. Signal. 2011, 23, 609-620. [CrossRef]

2. Chen, D.; Zhao, M.; Mundy, G.R. Bone Morphogenetic Proteins. Growth Factors 2004, 22, 233-241. [CrossRef] [PubMed]

3. Poniatowski, Ł.; Wojdasiewicz, P.; Gasik, R.; Szukiewicz, D. Transforming Growth Factor Beta Family: Insight into the Role of Growth Factors in Regulation of Fracture Healing Biology and Potential Clinical Applications. Mediat. Inflamm. 2015, 2015, 137823. [CrossRef] [PubMed]

4. Beyer, T.A.; Narimatsu, M.; Weiss, A.; David, L.; Wrana, J.L. The TGF $\beta$ superfamily in stem cell biology and early mammalian embryonic development. Biochim. Biophys. Acta 2013, 1830, 2268-2279. [CrossRef] [PubMed]

5. Weiss, A.; Attisano, L. The TGFbeta Superfamily Signaling Pathway. Wiley Interdiscip. Rev. Dev. Biol. 2013, 2, 47-63. [CrossRef]

6. Schlange, T.; Andrée, B.; Arnold, H.-H.; Brand, T. BMP2 is required for early heart development during a distinct time period. Mech. Dev. 2000, 91, 259-270. [CrossRef]

7. Robert, B. Bone morphogenetic protein signaling in limb outgrowth and patterning. Dev. Growth Differ. 2007, 49, 455-468. [CrossRef]

8. Maatouk, D.M.; Choi, K.-S.; Bouldin, C.M.; Harfe, B.D. In the limb AER Bmp2 and Bmp4 are required for dorsal-ventral patterning and interdigital cell death but not limb outgrowth. Dev. Biol. 2009, 327, 516-523. [CrossRef] 
9. McMahon, J.A.; Takada, S.; Zimmerman, L.B.; Fan, C.-M.; Harland, R.M.; McMahon, A.P. Noggin-mediated antagonism of BMP signaling is required for growth and patterning of the neural tube and somite. Genes Dev. 1998, 12, 1438-1452. [CrossRef]

10. Reshef, R.; Maroto, M.; Lassar, A.B. Regulation of dorsal somitic cell fates: BMPs and Noggin control the timing and pattern of myogenic regulator expression. Genes Dev. 1998, 12, 290-303. [CrossRef]

11. Bond, A.M.; Bhalala, O.G.; Kessler, J.A. The Dynamic Role of Bone Morphogenetic Proteins in Neural Stem Cell Fate and Maturation. Dev. Neurobiol. 2012, 72, 1068-1084. [CrossRef] [PubMed]

12. Nakashima, K.; Takizawa, T.; Ochiai, W.; Yanagisawa, M.; Hisatsune, T.; Nakafuku, M.; Miyazono, K.; Kishimoto, T.; Kageyama, R.; Taga, T. BMP2-mediated alteration in the developmental pathway of fetal mouse brain cells from neurogenesis to astrocytogenesis. Proc. Natl. Acad. Sci. USA 2001, 98, 5868-5873. [CrossRef] [PubMed]

13. Du, Y.; Xiao, Q.; Yip, H.K. Regulation of Retinal Progenitor Cell Differentiation by Bone Morphogenetic Protein 4 Is Mediated by the Smad/Id Cascade. Investig. Opthalmology Vis. Sci. 2010, 51, 3764-3773. [CrossRef] [PubMed]

14. Capulli, M.; Paone, R.; Rucci, N. Osteoblast and osteocyte: Games without frontiers. Arch. Biochem. Biophys. 2014, 561, 3-12. [CrossRef]

15. Bruderer, M.; Richards, R.G.; Alini, M.; Stoddart, M.J. Role and regulation of RUNX2 in osteogenesis. Eur. Cell Mater. 2014, 28, 269-286. [CrossRef] [PubMed]

16. Lee, S.Y.; Lee, J.H.; Kim, J.Y.; Bae, Y.C.; Suh, K.T.; Jung, J.S. BMP2 Increases Adipogenic Differentiation in the Presence of Dexamethasone, which is Inhibited by the Treatment of TNF-a in Human Adipose Tissue-Derived Stromal Cells. Cell. Physiol. Biochem. 2014, 34, 1339-1350. [CrossRef]

17. Sottile, V.; Seuwen, K. Bone morphogenetic protein-2 stimulates adipogenic differentiation of mesenchymal precursor cells in synergy with BRL 49653 (rosiglitazone). FEBS Lett. 2000, 475, 201-204. [CrossRef]

18. Zhou, N.; Li, Q.; Lin, X.; Hu, N.; Liao, J.-Y.; Lin, L.-B.; Zhao, C.; Hu, Z.-M.; Liang, X.; Xu, W.; et al. BMP2 induces chondrogenic differentiation, osteogenic differentiation and endochondral ossification in stem cells. Cell Tissue Res. 2016, 366, 101-111. [CrossRef]

19. Xu, S.C.; Harris, M.A.; Rubenstein, J.L.; Mundy, G.R.; Harris, S.E. Bone Morphogenetic Protein-2 (BMP-2) Signaling to the Col2 $\alpha 1$ Gene in Chondroblasts Requires the Homeobox Gene Dlx-2. DNA Cell Biol. 2001, 20, 359-365. [CrossRef]

20. Pajni-Underwood, S.; Wilson, C.P.; Elder, C.; Mishina, Y.; Lewandoski, M. BMP signals control limb bud interdigital programmed cell death by regulating FGF signaling. Development 2007, 134, 2359-2368. [CrossRef]

21. Macias, D.; Gañan, Y.; Sampath, T.K.; Piedra, M.E.; Ros, M.A.; Hurle, J.M. Role of BMP-2 and OP-1 (BMP-7) in programmed cell death and skeletogenesis during chick limb development. Development 1997, 124, 1109-1117. [PubMed]

22. Gámez, B.; Rodríguez-Carballo, E.; Ventura, F. BMP signaling in telencephalic neural cell specification and maturation. Front. Cell. Neurosci. 2013, 7, 87. [CrossRef] [PubMed]

23. Ma, L.; Lu, M.-F.; Schwartz, R.J.; Martin, J.F. Bmp2 is essential for cardiac cushion epithelial-mesenchymal transition and myocardial patterning. Development 2005, 132, 5601-5611. [CrossRef] [PubMed]

24. Rivera-Feliciano, J.; Tabin, C.J. Bmp2 instructs cardiac progenitors to form the heart-valve-inducing field. Dev. Biol. 2006, 295, 580-588. [CrossRef] [PubMed]

25. van Wijk, B.; Moorman, A.F.; van den Hoff, M.J. Role of bone morphogenetic proteins in cardiac differentiation. Cardiovasc. Res. 2007, 74, 244-255. [CrossRef] [PubMed]

26. Wang, J.; Greene, S.B.; Martin, J.F. BMP signaling in congenital heart disease: New developments and future directions. Birth Defects Res. Part A Clin. Mol. Teratol. 2011, 91, 441-448. [CrossRef] [PubMed]

27. Urist, M.R. Bone: Formation by Autoinduction. Science 1965, 150, 893-899. [CrossRef] [PubMed]

28. Zou, H.; Niswander, L.A. Requirement for BMP Signaling in Interdigital Apoptosis and Scale Formation. Science 1996, 272, 738-741. [CrossRef]

29. Christen, B.; Rodrigues, A.M.C.; Monasterio, M.B.; Roig, C.F.; Izpisua Belmonte, J.I. Transient downregulation of Bmp signalling induces extra limbs in vertebrates. Development 2012, 139, 2557-2565. [CrossRef]

30. Benavente, F.; Pinto, C.; Parada, M.; Henríquez, J.P.; Osses, N. Bone morphogenetic protein 2 inhibits neurite outgrowth of motor neuron-like NSC-34 cells and up-regulates its type II receptor. J. Neurochem. 2012, 122, 594-604. [CrossRef] 
31. Vrathasha, V.; Weidner, H.; Nohe, A. Mechanism of CK2.3, a Novel Mimetic Peptide of Bone Morphogenetic Protein Receptor Type IA, Mediated Osteogenesis. Int. J. Mol. Sci. 2019, 20, 2500. [CrossRef]

32. Shu, B.; Zhang, M.; Xie, R.; Wang, M.; Jin, H.; Hou, W.; Tang, D.; Harris, S.E.; Mishina, Y.; O’Keefe, R.J.; et al. $\mathrm{BMP} 2$, but not $\mathrm{BMP} 4$, is crucial for chondrocyte proliferation and maturation during endochondral bone development. J. Cell Sci. 2011, 124, 3428-3440. [CrossRef] [PubMed]

33. Huntley, R.; Jensen, E.; Gopalakrishnan, R.; Mansky, K.C. Bone morphogenetic proteins: Their role in regulating osteoclast differentiation. Bone Rep. 2019, 10, 100207. [CrossRef] [PubMed]

34. Wang, R.N.; Green, J.; Wang, Z.; Deng, Y.; Qiao, M.; Peabody, M.; Zhang, Q.; Ye, J.; Yan, Z.; Denduluri, S.; et al. Bone Morphogenetic Protein (BMP) signaling in development and human diseases. Genes Dis. 2014, 1, 87-105. [CrossRef]

35. Zhang, H.; Bradley, A. Mice deficient for BMP2 are nonviable and have defects in amnion/chorion and cardiac development. Development 1996, 122, 2977-2986. [PubMed]

36. Downey, P.A.; Siegel, M.I. Bone Biology and the Clinical Implications for Osteoporosis. Phys. Ther. 2006, 86, 77-91. [CrossRef] [PubMed]

37. McBride, S.H.; McKenzie, J.A.; Bedrick, B.S.; Kuhlmann, P.; Pasteris, J.D.; Rosen, V.; Silva, M.J. Long Bone Structure and Strength Depend on BMP2 from Osteoblasts and Osteocytes, but Not Vascular Endothelial Cells. PLoS ONE 2014, 9, e96862. [CrossRef] [PubMed]

38. Steele, D.G.; Bramblett, C.A. The Anatomy and Biology of the Human Skeleton; Texas A\&M University Press: College Station, TX, USA, 1988.

39. Buckwalter, J.A.; Glimcher, M.J.; Cooper, R.R.; Recker, R. Bone biology. I: Structure, blood supply, cells, matrix, and mineralization. Instr. Course Lect. 1996, 45, 371-386.

40. Sims, N.A.; Gooi, J.H. Bone remodeling: Multiple cellular interactions required for coupling of bone formation and resorption. Semin. Cell Dev. Biol. 2008, 19, 444-451. [CrossRef]

41. Florencio-Silva, R.; Sasso, G.R.; Sasso-Cerri, E.; Simões, M.J.; Cerri, P.S. Biology of Bone Tissue: Structure, Function, and Factors That Influence Bone Cells. BioMed Res. Int. 2015, 2015, 421746. [CrossRef]

42. Kawai, M.; de Paula, F.J.; Rosen, C.J. New insights into osteoporosis: The bone-fat connection. J. Intern. Med. 2012, 272, 317-329. [CrossRef] [PubMed]

43. The Basics of Bone in Health and Disease. Available online: https://www.ncbi.nlm.nih.gov/books/NBK45504/ (accessed on 23 April 2020).

44. Wu, Y.; Humphrey, M.B.; Nakamura, M.C. Osteoclasts-The innate immune cells of the bone. Autoimmunity 2008, 41, 183-194. [CrossRef] [PubMed]

45. Madel, M.B.; Ibáñez, L.; Wakkach, A.; de Vries, T.J.; Teti, A.; Apparailly, F.; Blin-Wakkach, C. Immune Function and Diversity of Osteoclasts in Normal and Pathological Conditions. Front. Immunol. 2019, 10, 1408. [CrossRef] [PubMed]

46. Jensen, E.D.; Pham, L.; Billington, C.J.; Espe, K.; Carlson, A.E.; Westendorf, J.J.; Petryk, A.; Gopalakrishnan, R.; Mansky, K. Bone morphogenic protein 2 directly enhances differentiation of murine osteoclast precursors. J. Cell. Biochem. 2010, 109, 672-682. [CrossRef]

47. Pham, L.; Beyer, K.; Jensen, E.D.; Rodriguez, J.S.; Davydova, J.; Yamamoto, M.; Petryk, A.; Gopalakrishnan, R.; Mansky, K.C. Bone morphogenetic protein 2 signaling in osteoclasts is negatively regulated by the BMP antagonist, twisted gastrulation. J. Cell. Biochem. 2011, 112, 793-803. [CrossRef]

48. Tannoury, C.A.; An, H.S. Complications with the use of bone morphogenetic protein 2 (BMP-2) in spine surgery. Spine J. 2014, 14, 552-559. [CrossRef]

49. Burkus, J.K.; Dorchak, J.D.; Sanders, D.L. Radiographic Assessment of Interbody Fusion Using Recombinant Human Bone Morphogenetic Protein Type 2. Spine 2003, 28, 372-377. [CrossRef]

50. Burkus, J.K.; Gornet, M.F.; Dickman, C.A.; Zdeblick, T.A. Anterior Lumbar Interbody Fusion Using rhBMP-2 with Tapered Interbody Cages. J. Spinal Disord. Tech. 2002, 15, 337-349. [CrossRef]

51. Haid, R.W.; Branch, C.L.; Alexander, J.T.; Burkus, J.K. Posterior lumbar interbody fusion using recombinant human bone morphogenetic protein type 2 with cylindrical interbody cages. Spine J. 2004, 4, 527-538; discussion 529-538. [CrossRef]

52. Smoljanovic, T.; Bojanic, I.; Dokuzovic, S. Re: Mindea SA, Shih P, Song JK. Recombinant human bone morphogenetic protein-2-induced radiculitis in elective minimally invasive transforaminal lumbar interbody fusions: A series review. Spine 2009;34:1480-5. Spine 2010, 35, 929. [CrossRef] 
53. Mindea, S.A.; Shih, P.; Song, J.K. Recombinant human bone morphogenetic protein-2-induced radiculitis in elective minimally invasive transforaminal lumbar interbody fusions: A series review. Spine 2009, 34, 1480-1484; discussion 1485. [CrossRef] [PubMed]

54. Tumialán, L.M.; Pan, J.; Rodts, G.E.; Mummaneni, P.V. The safety and efficacy of anterior cervical discectomy and fusion with polyetheretherketone spacer and recombinant human bone morphogenetic protein-2: A review of 200 patients. J. Neurosurgery Spine 2008, 8, 529-535. [CrossRef] [PubMed]

55. Shields, L.B.; Raque, G.H.; Glassman, S.D.; Campbell, M.; Vitaz, T.; Harpring, J.; Shields, C.B. Adverse Effects Associated with High-Dose Recombinant Human Bone Morphogenetic Protein-2 Use in Anterior Cervical Spine Fusion. Spine 2006, 31, 542-547. [CrossRef] [PubMed]

56. McClellan, J.W.; Mulconrey, D.S.; Forbes, R.J.; Fullmer, N. Vertebral Bone Resorption after Transforaminal Lumbar Interbody Fusion with Bone Morphogenetic Protein (rhBMP-2). J. Spinal Disord. Tech. 2006, 19, 483-486. [CrossRef] [PubMed]

57. Lewandrowski, K.-U.; Nanson, C.; Calderon, R. Vertebral osteolysis after posterior interbody lumbar fusion with recombinant human bone morphogenetic protein 2: A report of five cases. Spine J. 2007, 7, 609-614. [CrossRef]

58. Hashimoto, K.; Kaito, T.; Furuya, M.; Seno, S.; Okuzaki, D.; Kikuta, J.; Tsukazaki, H.; Matsuda, H.; Yoshikawa, H.; Ishii, M. In vivo dynamic analysis of BMP-2-induced ectopic bone formation. Sci. Rep. 2020, 10, 4751. [CrossRef]

59. Castranio, T.; Mishina, Y. Bmp2 is required for cephalic neural tube closure in the mouse. Dev. Dyn. 2009, 238, 110-122. [CrossRef]

60. Hogan, B.L. Bone morphogenetic proteins in development. Curr. Opin. Genet. Dev. 1996, 6, $432-438$. [CrossRef]

61. Mishina, Y. Function of bone morphogenetic protein signaling during mouse development. Front. Biosci. 2003, 8, d855-d869. [CrossRef]

62. Whitman, M. Smads and early developmental signaling by the TGFbeta superfamily. Genes Dev. 1998, 12, 2445-2462. [CrossRef]

63. Nifuji, A.; Kellermann, O.; Kuboki, Y.; Wozney, J.M.; Noda, M. Perturbation of BMP Signaling in Somitogenesis Resulted in Vertebral and Rib Malformations in the Axial Skeletal Formation. J. Bone Miner. Res. 1997, 12, 332-342. [CrossRef] [PubMed]

64. Wu, M.; Chen, G.; Li, Y.-P. TGF- $\beta$ and BMP signaling in osteoblast, skeletal development, and bone formation, homeostasis and disease. Bone Res. 2016, 4, 16009. [CrossRef] [PubMed]

65. Geetha-Loganathan, P.; Nimmagadda, S.; Huang, R.; Scaal, M.; Christ, B. Expression pattern of BMPs during chick limb development. Brain Struct. Funct. 2006, 211 (Suppl. 1), 87-93. [CrossRef]

66. Stottmann, R.W.; Klingensmith, J. Bone morphogenetic protein signaling is required in the dorsal neural folds before neurulation for the induction of spinal neural crest cells and dorsal neurons. Dev. Dyn. 2011, 240, 755-765. [CrossRef] [PubMed]

67. Li, H.; Wu, J.; Cui, D.; Zeng, J. Retinal and choroidal expression of BMP-2 in lens-induced myopia and recovery from myopia in guinea pigs. Mol. Med. Rep. 2016, 13, 2671-2676. [CrossRef]

68. Li, H.; Cui, D.; Zhao, F.; Huo, L.; Hu, J.; Zeng, J. BMP-2 Is Involved in Scleral Remodeling in Myopia Development. PLoS ONE 2015, 10, e0125219. [CrossRef]

69. Liu, H.-P.; Lin, Y.-J.; Lin, W.-Y.; Wan, L.; Sheu, J.J.-C.; Lin, H.-J.; Tsai, Y.; Tsai, C.-H.; Tsai, F.-J. A novel genetic variant ofBMP2Kcontributes to high myopia. J. Clin. Lab. Anal. 2009, 23, 362-367. [CrossRef]

70. Bandyopadhyay, A.; Tsuji, K.; Cox, K.; Harfe, B.D.; Rosen, V.; Tabin, C.J. Genetic Analysis of the Roles of BMP2, BMP4, and BMP7 in Limb Patterning and Skeletogenesis. PLoS Genet. 2006, 2, e216. [CrossRef]

71. Angello, J.C.; Kaestner, S.; Welikson, R.E.; Buskin, J.N.; Hauschka, S.D. BMP induction of cardiogenesis in P19 cells requires prior cell-cell interaction(s). Dev. Dyn. 2006, 235, 2122-2133. [CrossRef]

72. Wang, Y.X.; Qian, L.X.; Liu, D.; Yao, L.L.; Jiang, Q.; Yu, Z.; Gui, Y.H.; Zhong, T.P.; Song, H.Y. Bone morphogenetic protein-2 acts upstream of myocyte-specific enhancer factor 2a to control embryonic cardiac contractility. Cardiovasc. Res. 2007, 74, 290-303. [CrossRef]

73. Ying, Y.; Zhao, G.Q. Cooperation of endoderm-derived BMP2 and extraembryonic ectoderm-derived BMP4 in primordial germ cell generation in the mouse. Dev. Biol. 2001, 232, 484-492. [CrossRef] 
74. Tan, T.Y.; Gonzaga-Jauregui, C.; Bhoj, E.J.; Strauss, K.A.; Brigatti, K.; Puffenberger, E.G.; Li, D.; Xie, L.; Das, N.; Skubas, I.; et al. Monoallelic BMP2 Variants Predicted to Result in Haploinsufficiency Cause Craniofacial, Skeletal, and Cardiac Features Overlapping Those of 20p12 Deletions. Am. J. Hum. Genet. 2017, 101, 985-994. [CrossRef] [PubMed]

75. Sountoulidis, A.; Stavropoulos, A.; Giaglis, S.; Apostolou, E.; Monteiro, R.; Chuva de Sousa Lopes, S.M.; Chen, H.; Stripp, B.R.; Mummery, C.; Andreakos, E.; et al. Activation of the Canonical Bone Morphogenetic Protein (BMP) Pathway during Lung Morphogenesis and Adult Lung Tissue Repair. PLoS ONE 2012, 7, e41460. [CrossRef] [PubMed]

76. Warburton, D.; Bellusci, S.; De Langhe, S.; Del Moral, P.-M.; Fleury, V.; Mailleux, A.; Tefft, D.; Unbekandt, M.; Wang, K.; Shi, W. Molecular Mechanisms of Early Lung Specification and Branching Morphogenesis. Pediatr. Res. 2005, 57, 26R-37R. [CrossRef]

77. Southwood, M.; Jeffery, T.K.; Yang, X.; Upton, P.D.; Hall, S.M.; Atkinson, C.; Haworth, S.G.; Stewart, S.; Reynolds, P.N.; Long, L.; et al. Regulation of bone morphogenetic protein signalling in human pulmonary vascular development. J. Pathol. 2008, 214, 85-95. [CrossRef] [PubMed]

78. Kopf, J.; Petersen, A.; Duda, G.N.; Knaus, P. BMP2 and mechanical loading cooperatively regulate immediate early signalling events in the BMP pathway. BMC Biol. 2012, 10, 37. [CrossRef]

79. Huang, H.; Song, T.-J.; Li, X.; Hu, L.; He, Q.; Liu, M.; Lane, M.D.; Tang, Q.-Q. BMP signaling pathway is required for commitment of $\mathrm{C} 3 \mathrm{H} 10 \mathrm{~T} 1 / 2$ pluripotent stem cells to the adipocyte lineage. Proc. Natl. Acad. Sci. USA 2009, 106, 12670-12675. [CrossRef]

80. Denton, N.F.; Eghleilib, M.; Al-Sharifi, S.; Todorčević, M.; Neville, M.J.; Loh, N.; Drakesmith, H.; Karpe, F.; Pinnick, K. Correction to: Bone morphogenetic protein 2 is a depot-specific regulator of human adipogenesis. Int. J. Obes. 2019, 43, 2593. [CrossRef]

81. Dathe, K.; Kjaer, K.W.; Brehm, A.; Meinecke, P.; Nürnberg, P.; Neto, J.C.; Brunoni, D.; Tommerup, N.; Ott, C.E.; Klopocki, E.; et al. Duplications involving a conserved regulatory element downstream of BMP2 are associated with brachydactyly type A2. Am. J. Hum. Genet. 2009, 84, 483-492. [CrossRef]

82. Lehmann, K.; Seemann, P.; Silan, F.; Goecke, T.O.; Irgang, S.; Kjaer, K.W.; Kjaergaard, S.; Mahoney, M.J.; Morlot, S.; Reissner, C.; et al. A new subtype of brachydactyly type B caused by point mutations in the bone morphogenetic protein antagonist NOGGIN. Am. J. Hum. Genet. 2007, 81, 388-396. [CrossRef]

83. Goldman, D.C.; Donley, N.; Christian, J.L. Genetic interaction between Bmp2 and Bmp4 reveals shared functions during multiple aspects of mouse organogenesis. Mech. Dev. 2009, 126, 117-127. [CrossRef] [PubMed]

84. Heng, S.; Paule, S.G.; Hardman, B.; Li, Y.; Singh, H.; Rainczuk, A.; Stephens, A.N.; Nie, G. Posttranslational Activation of Bone Morphogenetic Protein 2 Is Mediated by Proprotein Convertase 6 during Decidualization for Pregnancy Establishment. Endocrinology 2010, 151, 3909-3917. [CrossRef] [PubMed]

85. Chen, G.; Deng, C.-X.; Li, Y.-P. TGF- $\beta$ and BMP Signaling in Osteoblast Differentiation and Bone Formation. Int. J. Biol. Sci. 2012, 8, 272-288. [CrossRef]

86. Wagner, I.; Wang, H.; Weissert, P.M.; Straube, W.L.; Shevchenko, A.; Gentzel, M.; Brito, G.; Tazaki, A.; Oliveira, C.; Sugiura, T.; et al. Serum Proteases Potentiate BMP-Induced Cell Cycle Re-entry of Dedifferentiating Muscle Cells during Newt Limb Regeneration. Dev. Cell 2017, 40, 608-617.e606. [CrossRef] [PubMed]

87. Umulis, D.; O'Connor, M.B.; Blair, S.S. The extracellular regulation of bone morphogenetic protein signaling. Development 2009, 136, 3715-3728. [CrossRef]

88. Heldin, C.H.; Miyazono, K.; ten Dijke, P. TGF-beta signalling from cell membrane to nucleus through SMAD proteins. Nature 1997, 390, 465-471. [CrossRef]

89. Horbelt, D.; Denkis, A.; Knaus, P. A portrait of Transforming Growth Factor $\beta$ superfamily signalling: Background matters. Int. J. Biochem. Cell Biol. 2012, 44, 469-474. [CrossRef]

90. Ikeda, T.; Takahashi, H.; Suzuki, A.; Ueno, N.; Yokose, S.; Yamaguchi, A.; Yoshiki, S. Cloning of rat type I receptor cDNA for bone morphogenetic protein-2 and bone morphogenetic protein-4, and the localization compared with that of the ligands. Dev. Dyn. 1996, 206, 318-329. [CrossRef]

91. Dewulf, N.; Verschueren, K.; Lonnoy, O.; Morén, A.; Grimsby, S.; Vande Spiegle, K.; Miyazono, K.; Huylebroeck, D.; Ten Dijke, P. Distinct spatial and temporal expression patterns of two type I receptors for bone morphogenetic proteins during mouse embryogenesis. Endocrinology 1995, 136, 2652-2663. [CrossRef] 
92. Yamaguchi, A.; Komori, T.; Suda, T. Regulation of Osteoblast Differentiation Mediated by Bone Morphogenetic Proteins, Hedgehogs, and Cbfa1. Endocr. Rev. 2000, 21, 393-411. [CrossRef]

93. Klages, J.; Kotzsch, A.; Coles, M.; Sebald, W.; Nickel, J.; Müller, T.; Kessler, H. The solution structure of BMPR-IA reveals a local disorder-to-order transition upon BMP-2 binding. Biochemistry 2008, 47, 11930-11939. [CrossRef]

94. Heinecke, K.; Seher, A.; Schmitz, W.; Mueller, T.; Sebald, W.; Nickel, J. Receptor oligomerization and beyond: A case study in bone morphogenetic proteins. BMC Biol. 2009, 7, 59. [CrossRef]

95. Gilboa, L.; Nohe, A.; Geissendörfer, T.; Sebald, W.; Henis, Y.I.; Knaus, P. Bone Morphogenetic Protein Receptor Complexes on the Surface of Live Cells: A New Oligomerization Mode for Serine/Threonine Kinase Receptors. Mol. Biol. Cell 2000, 11, 1023-1035. [CrossRef] [PubMed]

96. Saldanha, S.; Bragdon, B.; Moseychuk, O.; Bonor, J.; Dhurjati, P.; Nohe, A. Caveolae regulate smad signaling as verified by novel imaging and system biology approaches. J. Cell. Physiol. 2013, 228, 1060-1069. [CrossRef]

97. Hartung, A.; Bitton-Worms, K.; Rechtman, M.M.; Wenzel, V.; Boergermann, J.H.; Hassel, S.; Henis, Y.I.; Knaus, P. Different Routes of Bone Morphogenic Protein (BMP) Receptor Endocytosis Influence BMP Signaling. Mol. Cell. Biol. 2006, 26, 7791-7805. [CrossRef]

98. Bragdon, B.; Thinakaran, S.; Bonor, J.; Underhill, T.M.; Petersen, N.O.; Nohe, A. FRET Reveals Novel Protein-Receptor Interaction of Bone Morphogenetic Proteins Receptors and Adaptor Protein 2 at the Cell Surface. Biophys. J. 2009, 97, 1428-1435. [CrossRef] [PubMed]

99. Bonor, J.; Adams, E.L.; Bragdon, B.; Moseychuk, O.; Czymmek, K.J.; Nohe, A. Initiation of BMP2 signaling in domains on the plasma membrane. J. Cell. Physiol. 2012, 227, 2880-2888. [CrossRef] [PubMed]

100. Ramos, M.; Lamé, M.W.; Segall, H.J.; Wilson, D.W. The BMP type II receptor is located in lipid rafts, including caveolae, of pulmonary endothelium in vivo and in vitro. Vasc. Pharmacol. 2006, 44, 50-59. [CrossRef]

101. Bragdon, B.; Bonor, J.; Shultz, K.L.; Beamer, W.G.; Rosen, C.J.; Nohe, A. Bone morphogenetic protein receptor type Ia localization causes increased BMP2 signaling in mice exhibiting increased peak bone mass phenotype. J. Cell. Physiol. 2012, 227, 2870-2879. [CrossRef]

102. Aretz, S.; Stienen, D.; Uhlhaas, S.; Stolte, M.; Entius, M.M.; Loff, S.; Back, W.; Kaufmann, A.; Keller, K.M.; Blaas, S.H.; et al. High proportion of large genomic deletions and a genotype phenotype update in 80 unrelated families with juvenile polyposis syndrome. J. Med. Genet. 2007, 44, 702-709. [CrossRef]

103. Brosens, L.A.; Langeveld, D.; van Hattem, W.A.; Giardiello, F.M.; Offerhaus, G.J. Juvenile polyposis syndrome. World J. Gastroenterol. 2011, 17, 4839-4844. [CrossRef] [PubMed]

104. Calva-Cerqueira, D.; Chinnathambi, S.; Pechman, B.; Bair, J.; Larsen-Haidle, J.; Howe, J.R. The rate of germline mutations and large deletions of SMAD4 and BMPR1A in juvenile polyposis. Clin. Genet. 2009, 75, 79-85. [CrossRef]

105. Chow, E.; Macrae, F. A review of juvenile polyposis syndrome. J. Gastroenterol. Hepatol. 2005, 20, 1634-1640. [CrossRef] [PubMed]

106. Howe, J.R.; Sayed, M.G.; Ahmed, A.F.; Ringold, J.; Larsen-Haidle, J.; Merg, A.; Mitros, F.A.; Vaccaro, C.A.; Petersen, G.M.; Giardiello, F.M.; et al. The prevalence of MADH4 and BMPR1A mutations in juvenile polyposis and absence of BMPR2, BMPR1B, and ACVR1 mutations. J. Med. Genet. 2004, 41, 484-491. [CrossRef]

107. Pyatt, R.E.; Pilarski, R.; Prior, T.W. Mutation screening in juvenile polyposis syndrome. J. Mol. Diagn. 2006, 8, 84-88. [CrossRef]

108. Nohe, A.; Keating, E.; Knaus, P.; Petersen, N.O. Signal transduction of bone morphogenetic protein receptors. Cell. Signal. 2004, 16, 291-299. [CrossRef]

109. Nohe, A.; Hassel, S.; Ehrlich, M.; Neubauer, F.; Sebald, W.; Henis, Y.I.; Knaus, P. The mode of bone morphogenetic protein (BMP) receptor oligomerization determines different BMP-2 signaling pathways. J. Biol. Chem. 2002, 277, 5330-5338. [CrossRef] [PubMed]

110. Cejalvo, T.; Sacedón, R.; Hernández-López, C.; Diez, B.; Gutierrez-Frías, C.; Valencia, J.; Zapata, A.G.; Varas, A.; Vicente, A. Bone morphogenetic protein-2/4 signalling pathway components are expressed in the human thymus and inhibit early T-cell development. Immunology 2007, 121, 94-104. [CrossRef]

111. Rajagopal, R.; Huang, J.; Dattilo, L.K.; Kaartinen, V.; Mishina, Y.; Deng, C.X.; Umans, L.; Zwijsen, A.; Roberts, A.B.; Beebe, D.C. The type I BMP receptors, Bmpr1a and Acvr1, activate multiple signaling pathways to regulate lens formation. Dev. Biol. 2009, 335, 305-316. [CrossRef] 
112. Gomez-Puerto, M.C.; Iyengar, P.V.; García de Vinuesa, A.; Ten Dijke, P.; Sanchez-Duffhues, G. Bone morphogenetic protein receptor signal transduction in human disease. J. Pathol. 2019, 247, 9-20. [CrossRef]

113. Nohe, A.; Keating, E.; Underhill, T.M.; Knaus, P.; Petersen, N.O. Effect of the distribution and clustering of the type I A BMP receptor (ALK3) with the type II BMP receptor on the activation of signalling pathways. J. Cell Sci. 2003, 116, 3277-3284. [CrossRef]

114. Nohe, A.; Keating, E.; Underhill, T.M.; Knaus, P.; Petersen, N.O. Dynamics and interaction of caveolin-1 isoforms with BMP-receptors. J. Cell Sci. 2005, 118, 643-650. [CrossRef]

115. Akkiraju, H.; Bonor, J.; Nohe, A. CK2.1, a novel peptide, induces articular cartilage formation in vivo. J. Orthop. Res. 2017, 35, 876-885. [CrossRef] [PubMed]

116. Tramullas, M.; Lantero, A.; Díaz, A.; Morchón, N.; Merino, D.; Villar, A.; Buscher, D.; Merino, R.; Hurlé, J.M.; Izpisúa-Belmonte, J.C.; et al. BAMBI (bone morphogenetic protein and activin membrane-bound inhibitor) reveals the involvement of the transforming growth factor-beta family in pain modulation. J. Neurosci. 2010, 30, 1502-1511. [CrossRef] [PubMed]

117. Luo, X.; Hutley, L.J.; Webster, J.A.; Kim, Y.H.; Liu, D.F.; Newell, F.S.; Widberg, C.H.; Bachmann, A.; Turner, N.; Schmitz-Peiffer, C.; et al. Identification of BMP and activin membrane-bound inhibitor (BAMBI) as a potent negative regulator of adipogenesis and modulator of autocrine/paracrine adipogenic factors. Diabetes 2012, 61, 124-136. [CrossRef] [PubMed]

118. Bai, L.; Chang, H.M.; Cheng, J.C.; Klausen, C.; Chu, G.; Leung, P.C.K.; Yang, G. SMAD1/5 mediates bone morphogenetic protein 2-induced up-regulation of BAMBI expression in human granulosa-lutein cells. Cell. Signal. 2017, 37, 52-61. [CrossRef] [PubMed]

119. Samad, T.A.; Rebbapragada, A.; Bell, E.; Zhang, Y.; Sidis, Y.; Jeong, S.J.; Campagna, J.A.; Perusini, S.; Fabrizio, D.A.; Schneyer, A.L.; et al. DRAGON, a bone morphogenetic protein co-receptor. J. Biol. Chem. 2005, 280, 14122-14129. [CrossRef] [PubMed]

120. Corradini, E.; Babitt, J.L.; Lin, H.Y. The RGM/DRAGON family of BMP co-receptors. Cytokine Growth Factor Rev. 2009, 20, 389-398. [CrossRef] [PubMed]

121. Xia, Y.; Babitt, J.L.; Bouley, R.; Zhang, Y.; Da Silva, N.; Chen, S.; Zhuang, Z.; Samad, T.A.; Brenner, G.J.; Anderson, J.L.; et al. Dragon enhances BMP signaling and increases transepithelial resistance in kidney epithelial cells. J. Am. Soc. Nephrol. 2010, 21, 666-677. [CrossRef] [PubMed]

122. Saito, T.; Bokhove, M.; Croci, R.; Zamora-Caballero, S.; Han, L.; Letarte, M.; de Sanctis, D.; Jovine, L. Structural Basis of the Human Endoglin-BMP9 Interaction: Insights into BMP Signaling and HHT1. Cell Rep. 2017, 19, 1917-1928. [CrossRef]

123. Nickel, J.; Ten Dijke, P.; Mueller, T.D. TGF- $\beta$ family co-receptor function and signaling. Acta Biochim. Biophys. Sin. (Shanghai) 2018, 50, 12-36. [CrossRef] [PubMed]

124. López-Novoa, J.M.; Bernabeu, C. The physiological role of endoglin in the cardiovascular system. Am. J. Physiol. Heart Circ. Physiol. 2010, 299, H959-H974. [CrossRef] [PubMed]

125. López-Casillas, F.; Wrana, J.L.; Massagué, J. Betaglycan presents ligand to the TGF beta signaling receptor. Cell 1993, 73, 1435-1444. [CrossRef]

126. Gray, P.C.; Bilezikjian, L.M.; Vale, W. Antagonism of activin by inhibin and inhibin receptors: A functional role for betaglycan. Mol. Cell. Endocrinol. 2002, 188, 254-260. [CrossRef]

127. Klammert, U.; Mueller, T.D.; Hellmann, T.V.; Wuerzler, K.K.; Kotzsch, A.; Schliermann, A.; Schmitz, W.; Kuebler, A.C.; Sebald, W.; Nickel, J. GDF-5 can act as a context-dependent BMP-2 antagonist. BMC Biol. 2015, 13, 77. [CrossRef] [PubMed]

128. Villarreal, M.M.; Kim, S.K.; Barron, L.; Kodali, R.; Baardsnes, J.; Hinck, C.S.; Krzysiak, T.C.; Henen, M.A.; Pakhomova, O.; Mendoza, V.; et al. Binding Properties of the Transforming Growth Factor- $\beta$ Coreceptor Betaglycan: Proposed Mechanism for Potentiation of Receptor Complex Assembly and Signaling. Biochemistry 2016, 55, 6880-6896. [CrossRef] [PubMed]

129. Ruppert, R.; Hoffmann, E.; Sebald, W. Human bone morphogenetic protein 2 contains a heparin-binding site which modifies its biological activity. Eur. J. Biochem. 1996, 237, 295-302. [CrossRef]

130. Martino, M.M.; Briquez, P.S.; Ranga, A.; Lutolf, M.P.; Hubbell, J.A. Heparin-binding domain of fibrin(ogen) binds growth factors and promotes tissue repair when incorporated within a synthetic matrix. Proc. Natl. Acad. Sci. USA 2013, 110, 4563-4568. [CrossRef]

131. Bolten, S.N.; Rinas, U.; Scheper, T. Heparin: Role in protein purification and substitution with animal-component free material. Appl Microbiol Biotechnol 2018, 102, 8647-8660. [CrossRef] 
132. Migliorini, E.; Thakar, D.; Kühnle, J.; Sadir, R.; Dyer, D.P.; Li, Y.; Sun, C.; Volkman, B.F.; Handel, T.M.; Coche-Guerente, L.; et al. Cytokines and growth factors cross-link heparan sulfate. Open Biol. 2015, 5, 150046. [CrossRef]

133. De Laporte, L.; Rice, J.J.; Tortelli, F.; Hubbell, J.A. Tenascin C promiscuously binds growth factors via its fifth fibronectin type III-like domain. PLoS ONE 2013, 8, e62076. [CrossRef]

134. Yang, Y.L.; Liu, Y.S.; Chuang, L.Y.; Guh, J.Y.; Lee, T.C.; Liao, T.N.; Hung, M.Y.; Chiang, T.A. Bone morphogenetic protein-2 antagonizes renal interstitial fibrosis by promoting catabolism of type I transforming growth factor-beta receptors. Endocrinology 2009, 150, 727-740. [CrossRef] [PubMed]

135. Martino, M.M.; Hubbell, J.A. The 12th-14th type III repeats of fibronectin function as a highly promiscuous growth factor-binding domain. FASEB J. 2010, 24, 4711-4721. [CrossRef] [PubMed]

136. Hettiaratchi, M.H.; Krishnan, L.; Rouse, T.; Chou, C.; McDevitt, T.C.; Guldberg, R.E. Heparin-mediated delivery of bone morphogenetic protein-2 improves spatial localization of bone regeneration. Sci. Adv. 2020, 6, eaay1240. [CrossRef]

137. Zhao, B.; Katagiri, T.; Toyoda, H.; Takada, T.; Yanai, T.; Fukuda, T.; Chung, U.I.; Koike, T.; Takaoka, K.; Kamijo, R. Heparin potentiates the in vivo ectopic bone formation induced by bone morphogenetic protein-2. J. Biol. Chem. 2006, 281, 23246-23253. [CrossRef]

138. Migliorini, E.; Guevara-Garcia, A.; Albiges-Rizo, C.; Picart, C. Learning from BMPs and their biophysical extracellular matrix microenvironment for biomaterial design. Bone 2020, 115540. [CrossRef]

139. Utturkar, A.; Paul, B.; Akkiraju, H.; Bonor, J.; Dhurjati, P.; Nohe, A. Development of Physiologically Based Pharmacokinetic Model (PBPK) of BMP2 in Mice. Biol. Syst. Open Access 2013, 2. [CrossRef]

140. Kleinschmidt, K.; Ploeger, F.; Nickel, J.; Glockenmeier, J.; Kunz, P.; Richter, W. Enhanced reconstruction of long bone architecture by a growth factor mutant combining positive features of GDF-5 and BMP-2. Biomaterials 2013, 34, 5926-5936. [CrossRef]

141. Jing, D.; Hao, X.; Xu, F.; Liu, J.; Luo, E.; Meng, G. Effects of local delivery of BMP2, zoledronate and their combination on bone microarchitecture, biomechanics and bone turnover in osteoporotic rabbits. Sci. Rep. 2016, 6, 28537. [CrossRef]

142. Shen, J.; James, A.W.; Zara, J.N.; Asatrian, G.; Khadarian, K.; Zhang, J.B.; Ho, S.; Kim, H.J.; Ting, K.; Soo, C. BMP2-induced inflammation can be suppressed by the osteoinductive growth factor NELL-1. Tissue Eng. Part A 2013, 19, 2390-2401. [CrossRef]

143. Uchimura, T.; Komatsu, Y.; Tanaka, M.; McCann, K.L.; Mishina, Y. Bmp2 and Bmp4 genetically interact to support multiple aspects of mouse development including functional heart development. Genesis 2009, 47, 374-384. [CrossRef] [PubMed]

144. Scheufler, C.; Sebald, W.; Hülsmeyer, M. Crystal structure of human bone morphogenetic protein-2 at $2.7 \mathrm{~A}$ resolution. J. Mol. Biol. 1999, 287, 103-115. [CrossRef] [PubMed]

145. Luo, K.; Lodish, H.F. Signaling by chimeric erythropoietin-TGF-beta receptors: Homodimerization of the cytoplasmic domain of the type I TGF-beta receptor and heterodimerization with the type II receptor are both required for intracellular signal transduction. EMBO J. 1996, 15, 4485-4496. [CrossRef]

146. Luo, K.; Lodish, H.F. Positive and negative regulation of type II TGF-beta receptor signal transduction by autophosphorylation on multiple serine residues. EMBO J. 1997, 16, 1970-1981. [CrossRef] [PubMed]

147. Koenig, B.B.; Cook, J.S.; Wolsing, D.H.; Ting, J.; Tiesman, J.P.; Correa, P.E.; Olson, C.A.; Pecquet, A.L.; Ventura, F.; Grant, R.A. Characterization and cloning of a receptor for BMP-2 and BMP-4 from NIH 3T3 cells. Mol. Cell. Biol. 1994, 14, 5961-5974. [CrossRef]

148. Nickel, J.; Dreyer, M.K.; Kirsch, T.; Sebald, W. The crystal structure of the BMP-2:BMPR-IA complex and the generation of BMP-2 antagonists. J. Bone Jt. Surg. 2001, 83 (Suppl. 1), S7-S14. [CrossRef]

149. Groppe, J.; Greenwald, J.; Wiater, E.; Rodriguez-Leon, J.; Economides, A.N.; Kwiatkowski, W.; Baban, K.; Affolter, M.; Vale, W.W.; Belmonte, J.I.; et al. Structural basis of BMP signaling inhibition by Noggin, a novel twelve-membered cystine knot protein. J. Bone Jt. Surg. 2003, 85, 52-58. [CrossRef]

150. Sakaguchi, M.; Sharmin, S.; Taguchi, A.; Ohmori, T.; Fujimura, S.; Abe, T.; Kiyonari, H.; Komatsu, Y.; Mishina, Y.; Asashima, M.; et al. The phosphatase Dullard negatively regulates BMP signalling and is essential for nephron maintenance after birth. Nat. Commun. 2013, 4, 1398. [CrossRef]

151. Sinha, K.M.; Zhou, X. Genetic and molecular control of osterix in skeletal formation. J. Cell Biochem. 2013, 114, 975-984. [CrossRef] 
152. Holtzhausen, A.; Golzio, C.; How, T.; Lee, Y.H.; Schiemann, W.P.; Katsanis, N.; Blobe, G.C. Novel bone morphogenetic protein signaling through Smad2 and Smad3 to regulate cancer progression and development. FASEB J. 2014, 28, 1248-1267. [CrossRef]

153. Wang, Y.; Ho, C.C.; Bang, E.; Rejon, C.A.; Libasci, V.; Pertchenko, P.; Hébert, T.E.; Bernard, D.J. Bone morphogenetic protein 2 stimulates noncanonical SMAD2/3 signaling via the BMP type 1A receptor in gonadotrope-like cells: Implications for FSH synthesis. Endocrinology 2014, 155, 1970-1981. [CrossRef] [PubMed]

154. Liu, L.; Liu, X.; Ren, X.; Tian, Y.; Chen, Z.; Xu, X.; Du, Y.; Jiang, C.; Fang, Y.; Liu, Z.; et al. Smad2 and Smad3 have differential sensitivity in relaying TGF $\beta$ signaling and inversely regulate early lineage specification. Sci. Rep. 2016, 6, 21602. [CrossRef] [PubMed]

155. Nickel, J.; Mueller, T.D. Specification of BMP Signaling. Cells 2019, 8, 1579. [CrossRef]

156. Bragdon, B.; Thinakaran, S.; Moseychuk, O.; King, D.; Young, K.; Litchfield, D.W.; Petersen, N.O.; Nohe, A. Casein kinase 2 beta-subunit is a regulator of bone morphogenetic protein 2 signaling. Biophys. J. 2010, 99, 897-904. [CrossRef] [PubMed]

157. Bragdon, B.; Thinakaran, S.; Moseychuk, O.; Gurski, L.; Bonor, J.; Price, C.; Wang, L.; Beamer, W.G.; Nohe, A. Casein kinase 2 regulates in vivo bone formation through its interaction with bone morphogenetic protein receptor type Ia. Bone 2011, 49, 944-954. [CrossRef] [PubMed]

158. Moseychuk, O.; Akkiraju, H.; Dutta, J.; D’Angelo, A.; Bragdon, B.; Duncan, R.L.; Nohe, A. Inhibition of CK2 binding to BMPRIa induces C2C12 differentiation into osteoblasts and adipocytes. J. Cell Commun. Signal. 2013, 7, 265-278. [CrossRef]

159. Zhang, Y.E. Non-Smad Signaling Pathways of the TGF- $\beta$ Family. Cold Spring Harb. Perspect.Biol. 2017, 9, a022129. [CrossRef]

160. Chang, J.; Wang, Z.; Tang, E.; Fan, Z.; McCauley, L.; Franceschi, R.; Guan, K.; Krebsbach, P.H.; Wang, C.-Y. Inhibition of Osteoblast Functions by IKK/NF- $\kappa$ B in Osteoporosis. Nat. Med. 2009, 15, 682-689. [CrossRef]

161. Yao, Z.; Li, Y.; Yin, X.; Dong, Y.; Xing, L.; Boyce, B.F. NF-кB RelB negatively regulates osteoblast differentiation and bone formation. J. Bone Miner. Res. 2014, 29, 866-877. [CrossRef]

162. Karner, C.M.; Lee, S.Y.; Long, F. Bmp Induces Osteoblast Differentiation through both Smad4 and mTORC1 Signaling. Mol. Cell. Biol. 2017, 37. [CrossRef]

163. Saito, A.; Ochiai, K.; Kondo, S.; Tsumagari, K.; Murakami, T.; Cavener, D.R.; Imaizumi, K. Endoplasmic reticulum stress response mediated by the PERK-eIF2(alpha)-ATF4 pathway is involved in osteoblast differentiation induced by BMP2. J. Biol. Chem. 2011, 286, 4809-4818. [CrossRef] [PubMed]

164. Huang, P.; Chen, A.; He, W.; Li, Z.; Zhang, G.; Liu, Z.; Liu, G.; Liu, X.; He, S.; Xiao, G.; et al. BMP-2 induces EMT and breast cancer stemness through Rb and CD44. Cell Death Discov. 2017, 3, 17039. [CrossRef] [PubMed]

165. Bragdon, B.; D’Angelo, A.; Gurski, L.; Bonor, J.; Schultz, K.L.; Beamer, W.G.; Rosen, C.J.; Nohe, A. Altered plasma membrane dynamics of bone morphogenetic protein receptor type Ia in a low bone mass mouse model. Bone 2012, 50, 189-199. [CrossRef] [PubMed]

166. Zamurovic, N.; Cappellen, D.; Rohner, D.; Susa, M. Coordinated activation of notch, Wnt, and transforming growth factor-beta signaling pathways in bone morphogenic protein 2-induced osteogenesis. Notch target gene Hey1 inhibits mineralization and Runx2 transcriptional activity. J. Biol. Chem. 2004, 279, 37704-37715. [CrossRef]

167. Papathanasiou, I.; Malizos, K.N.; Tsezou, A. Bone morphogenetic protein-2-induced Wnt/ß-catenin signaling pathway activation through enhanced low-density-lipoprotein receptor-related protein 5 catabolic activity contributes to hypertrophy in osteoarthritic chondrocytes. Arthritis Res. Ther. 2012, 14, R82. [CrossRef]

168. Eldar, A.; Dorfman, R.; Weiss, D.; Ashe, H.; Shilo, B.Z.; Barkai, N. Robustness of the BMP morphogen gradient in Drosophila embryonic patterning. Nature 2002, 419, 304-308. [CrossRef]

169. Bonds, M.; Sands, J.; Poulson, W.; Harvey, C.; Von Ohlen, T. Genetic screen for regulators of ind expression identifies shrew as encoding a novel twisted gastrulation-like protein involved in Dpp signaling. Dev. Dyn. 2007, 236, 3524-3531. [CrossRef]

170. Chang, C. Agonists and Antagonists of TGF- $\beta$ Family Ligands. Cold Spring Harb. Perspect. Biol. 2016, 8, a021923. [CrossRef]

171. Zakin, L.; De Robertis, E.M. Extracellular regulation of BMP signaling. Curr. Biol. 2010, 20, R89-R92. [CrossRef] 
172. Zhu, W.; Kim, J.; Cheng, C.; Rawlins, B.A.; Boachie-Adjei, O.; Crystal, R.G.; Hidaka, C. Noggin regulation of bone morphogenetic protein (BMP) 2/7 heterodimer activity in vitro. Bone 2006, 39, 61-71. [CrossRef]

173. Abe, Y.; Abe, T.; Aida, Y.; Hara, Y.; Maeda, K. Follistatin restricts bone morphogenetic protein (BMP)-2 action on the differentiation of osteoblasts in fetal rat mandibular cells. J. Bone Miner. Res. 2004, 19, 1302-1307. [CrossRef] [PubMed]

174. Migliorini, E.; Valat, A.; Picart, C.; Cavalcanti-Adam, E.A. Tuning cellular responses to BMP-2 with material surfaces. Cytokine Growth Factor Rev. 2016, 27, 43-54. [CrossRef] [PubMed]

175. Hauff, K.; Zambarda, C.; Dietrich, M.; Halbig, M.; Grab, A.L.; Medda, R.; Cavalcanti-Adam, E.A. Matrix-Immobilized BMP-2 on Microcontact Printed Fibronectin as an in vitro Tool to Study BMP-Mediated Signaling and Cell Migration. Front Bioeng. Biotechnol. 2015, 3, 62. [CrossRef] [PubMed]

176. Kisiel, M.; Klar, A.S.; Ventura, M.; Buijs, J.; Mafina, M.K.; Cool, S.M.; Hilborn, J. Complexation and sequestration of BMP-2 from an ECM mimetic hyaluronan gel for improved bone formation. PLoS ONE 2013, 8, e78551. [CrossRef]

177. Piccolo, S.; Sasai, Y.; Lu, B.; De Robertis, E.M. Dorsoventral patterning in Xenopus: Inhibition of ventral signals by direct binding of chordin to BMP-4. Cell 1996, 86, 589-598. [CrossRef]

178. Itoh, F.; Asao, H.; Sugamura, K.; Heldin, C.H.; ten Dijke, P.; Itoh, S. Promoting bone morphogenetic protein signaling through negative regulation of inhibitory Smads. EMBO J. 2001, 20, 4132-4142. [CrossRef]

179. Weidner, H.; Yuan Gao, V.; Dibert, D.; McTague, S.; Eskander, M.; Duncan, R.; Wang, L.; Nohe, A. CK2.3, a Mimetic Peptide of the BMP Type I Receptor, Increases Activity in Osteoblasts over BMP2. Int. J. Mol. Sci. 2019, 20, 5877. [CrossRef]

180. Stroud, D.M.; Gaussin, V.; Burch, J.B.; Yu, C.; Mishina, Y.; Schneider, M.D.; Fishman, G.I.; Morley, G.E. Abnormal conduction and morphology in the atrioventricular node of mice with atrioventricular canal targeted deletion of Alk3/Bmpr1a receptor. Circulation 2007, 116, 2535-2543. [CrossRef]

181. Gaussin, V.; Morley, G.E.; Cox, L.; Zwijsen, A.; Vance, K.M.; Emile, L.; Tian, Y.; Liu, J.; Hong, C.; Myers, D.; et al. Alk3/Bmpr1a receptor is required for development of the atrioventricular canal into valves and annulus fibrosus. Circ. Res. 2005, 97, 219-226. [CrossRef]

182. Nguyen, J.; Weidner, H.; Schell, L.M.; Sequeira, L.; Kabrick, R.; Dharmadhikari, S.; Coombs, H.; Duncan, R.L.; Wang, L.; Nohe, A. Synthetic Peptide CK2.3 Enhances Bone Mineral Density in Senile Mice. J. Bone Res. 2018, 6. [CrossRef]

183. Akkiraju, H.; Bonor, J.; Olli, K.; Bowen, C.; Bragdon, B.; Coombs, H.; Donahue, L.R.; Duncan, R.; Nohe, A. Systemic injection of CK2.3, a novel peptide acting downstream of bone morphogenetic protein receptor BMPRIa, leads to increased trabecular bone mass. J. Orthop. Res. 2015, 33, 208-215. [CrossRef] [PubMed]

184. Koike, N.; Kassai, Y.; Kouta, Y.; Miwa, H.; Konishi, M.; Itoh, N. Brorin, a novel secreted bone morphogenetic protein antagonist, promotes neurogenesis in mouse neural precursor cells. J. Biol. Chem. 2007, 282, 15843-15850. [CrossRef] [PubMed]

185. Miwa, H.; Miyake, A.; Kouta, Y.; Shimada, A.; Yamashita, Y.; Nakayama, Y.; Yamauchi, H.; Konishi, M.; Itoh, N. A novel neural-specific BMP antagonist, Brorin-like, of the Chordin family. FEBS Lett. 2009, 583, 3643-3648. [CrossRef] [PubMed]

186. Itoh, N.; Ohta, H. Secreted bone morphogenetic protein antagonists of the Chordin family. Biomol. Concepts 2010, 1, 297-304. [CrossRef] [PubMed]

187. Nolan, K.; Kattamuri, C.; Luedeke, D.M.; Deng, X.; Jagpal, A.; Zhang, F.; Linhardt, R.J.; Kenny, A.P.; Zorn, A.M.; Thompson, T.B. Structure of protein related to Dan and Cerberus: Insights into the mechanism of bone morphogenetic protein antagonism. Structure 2013, 21, 1417-1429. [CrossRef] [PubMed]

188. Canalis, E.; Economides, A.N.; Gazzerro, E. Bone morphogenetic proteins, their antagonists, and the skeleton. Endocr. Rev. 2003, 24, 218-235. [CrossRef]

189. Troilo, H.; Zuk, A.V.; Tunnicliffe, R.B.; Wohl, A.P.; Berry, R.; Collins, R.F.; Jowitt, T.A.; Sengle, G.; Baldock, C. Nanoscale structure of the BMP antagonist chordin supports cooperative BMP binding. Proc. Natl. Acad. Sci. USA 2014, 111, 13063-13068. [CrossRef]

190. Zhang, D.; Ferguson, C.M.; O’Keefe, R.J.; Puzas, J.E.; Rosier, R.N.; Reynolds, P.R. A role for the BMP antagonist chordin in endochondral ossification. J. Bone Miner. Res. 2002, 17, 293-300. [CrossRef]

191. Hung, W.T.; Wu, F.J.; Wang, C.J.; Luo, C.W. DAN (NBL1) specifically antagonizes BMP2 and BMP4 and modulates the actions of GDF9, BMP2, and BMP4 in the rat ovary. Biol. Reprod. 2012, 86, 158. [CrossRef] 
192. Amthor, H.; Christ, B.; Rashid-Doubell, F.; Kemp, C.F.; Lang, E.; Patel, K. Follistatin regulates bone morphogenetic protein-7 (BMP-7) activity to stimulate embryonic muscle growth. Dev. Biol. 2002, 243, 115-127. [CrossRef]

193. Fahmy-Garcia, S.; Farrell, E.; Witte-Bouma, J.; Robbesom-van den Berge, I.; Suarez, M.; Mumcuoglu, D.; Walles, H.; Kluijtmans, S.G.J.M.; van der Eerden, B.C.J.; van Osch, G.J.V.M.; et al. Follistatin Effects in Migration, Vascularization, and Osteogenesis. Front. Bioeng. Biotechnol. 2019, 7, 38. [CrossRef] [PubMed]

194. Maguer-Satta, V.; Bartholin, L.; Jeanpierre, S.; Ffrench, M.; Martel, S.; Magaud, J.P.; Rimokh, R. Regulation of human erythropoiesis by activin A, BMP2, and BMP4, members of the TGFbeta family. Exp. Cell Res. 2003, 282, 110-120. [CrossRef]

195. Tsuchida, K.; Arai, K.Y.; Kuramoto, Y.; Yamakawa, N.; Hasegawa, Y.; Sugino, H. Identification and characterization of a novel follistatin-like protein as a binding protein for the TGF-beta family. J. Biol. Chem. 2000, 275, 40788-40796. [CrossRef] [PubMed]

196. Bartholin, L.; Maguer-Satta, V.; Hayette, S.; Martel, S.; Gadoux, M.; Corbo, L.; Magaud, J.P.; Rimokh, R. Transcription activation of FLRG and follistatin by activin A, through Smad proteins, participates in a negative feedback loop to modulate activin A function. Oncogene 2002, 21, 2227-2235. [CrossRef] [PubMed]

197. Sanders, L.N.; Schoenhard, J.A.; Saleh, M.A.; Mukherjee, A.; Ryzhov, S.; McMaster, W.G.; Nolan, K.; Gumina, R.J.; Thompson, T.B.; Magnuson, M.A.; et al. BMP Antagonist Gremlin 2 Limits Inflammation After Myocardial Infarction. Circ. Res. 2016, 119, 434-449. [CrossRef]

198. Nolan, K.; Kattamuri, C.; Rankin, S.A.; Read, R.J.; Zorn, A.M.; Thompson, T.B. Structure of Gremlin-2 in Complex with GDF5 Gives Insight into DAN-Family-Mediated BMP Antagonism. Cell Rep. 2016, 16, 2077-2086. [CrossRef]

199. Choi, M.; Stottmann, R.W.; Yang, Y.P.; Meyers, E.N.; Klingensmith, J. The bone morphogenetic protein antagonist noggin regulates mammalian cardiac morphogenesis. Circ. Res. 2007, 100, 220-228. [CrossRef]

200. Zimmerman, L.B.; De Jesús-Escobar, J.M.; Harland, R.M. The Spemann organizer signal noggin binds and inactivates bone morphogenetic protein 4. Cell 1996, 86, 599-606. [CrossRef]

201. Li, X.; Zhang, Y.; Kang, H.; Liu, W.; Liu, P.; Zhang, J.; Harris, S.E.; Wu, D. Sclerostin binds to LRP5/6 and antagonizes canonical Wnt signaling. J. Biol. Chem. 2005, 280, 19883-19887. [CrossRef]

202. Lin, C.; Jiang, X.; Dai, Z.; Guo, X.; Weng, T.; Wang, J.; Li, Y.; Feng, G.; Gao, X.; He, L. Sclerostin mediates bone response to mechanical unloading through antagonizing Wnt/beta-catenin signaling. J. Bone Miner. Res. 2009, 24, 1651-1661. [CrossRef]

203. Baron, R.; Rawadi, G. Targeting the Wnt/beta-catenin pathway to regulate bone formation in the adult skeleton. Endocrinology 2007, 148, 2635-2643. [CrossRef] [PubMed]

204. Ominsky, M.S.; Niu, Q.T.; Li, C.; Li, X.; Ke, H.Z. Tissue-level mechanisms responsible for the increase in bone formation and bone volume by sclerostin antibody. J. Bone Miner. Res. 2014, 29, 1424-1430. [CrossRef] [PubMed]

205. Oelgeschläger, M.; Larraín, J.; Geissert, D.; De Robertis, E.M. The evolutionarily conserved BMP-binding protein Twisted gastrulation promotes BMP signalling. Nature 2000, 405, 757-763. [CrossRef] [PubMed]

206. Chang, C.; Holtzman, D.A.; Chau, S.; Chickering, T.; Woolf, E.A.; Holmgren, L.M.; Bodorova, J.; Gearing, D.P.; Holmes, W.E.; Brivanlou, A.H. Twisted gastrulation can function as a BMP antagonist. Nature 2001, 410, 483-487. [CrossRef]

207. Xie, J.; Fisher, S. Twisted gastrulation enhances BMP signaling through chordin dependent and independent mechanisms. Development 2005, 132, 383-391. [CrossRef]

208. Ross, J.J.; Shimmi, O.; Vilmos, P.; Petryk, A.; Kim, H.; Gaudenz, K.; Hermanson, S.; Ekker, S.C.; O'Connor, M.B.; Marsh, J.L. Twisted gastrulation is a conserved extracellular BMP antagonist. Nature 2001, 410, 479-483. [CrossRef]

209. Little, S.C.; Mullins, M.C. Twisted gastrulation promotes BMP signaling in zebrafish dorsal-ventral axial patterning. Development 2004, 131, 5825-5835. [CrossRef]

210. Troilo, H.; Barrett, A.L.; Zuk, A.V.; Lockhart-Cairns, M.P.; Wohl, A.P.; Bayley, C.P.; Dajani, R.; Tunnicliffe, R.B.; Green, L.; Jowitt, T.A.; et al. Structural characterization of twisted gastrulation provides insights into opposing functions on the BMP signalling pathway. Matrix Biol. 2016, 55, 49-62. [CrossRef]

211. Yanagita, M.; Oka, M.; Watabe, T.; Iguchi, H.; Niida, A.; Takahashi, S.; Akiyama, T.; Miyazono, K.; Yanagisawa, M.; Sakurai, T. USAG-1: A bone morphogenetic protein antagonist abundantly expressed in the kidney. Biochem. Biophys. Res. Commun. 2004, 316, 490-500. [CrossRef] 
212. Yanagita, M.; Okuda, T.; Endo, S.; Tanaka, M.; Takahashi, K.; Sugiyama, F.; Kunita, S.; Takahashi, S.; Fukatsu, A.; Yanagisawa, M.; et al. Uterine sensitization-associated gene-1 (USAG-1), a novel BMP antagonist expressed in the kidney, accelerates tubular injury. J. Clin. Investig. 2006, 116, 70-79. [CrossRef]

213. Ehrlich, M. Endocytosis and trafficking of BMP receptors: Regulatory mechanisms for fine-tuning the signaling response in different cellular contexts. Cytokine Growth Factor Rev. 2016, 27, 35-42. [CrossRef]

214. Khattar, V.; Lee, J.H.; Wang, H.; Bastola, S.; Ponnazhagan, S. Structural determinants and genetic modifications enhance BMP2 stability and extracellular secretion. FASEB BioAdvances 2019, 1, 180-190. [CrossRef] [PubMed]

215. Garrett, I.R.; Chen, D.; Gutierrez, G.; Zhao, M.; Escobedo, A.; Rossini, G.; Harris, S.E.; Gallwitz, W.; Kim, K.B.; $\mathrm{Hu}, \mathrm{S}$.; et al. Selective inhibitors of the osteoblast proteasome stimulate bone formation in vivo and in vitro. J. Clin. Investig. 2003, 111, 1771-1782. [CrossRef]

216. Satow, R.; Kurisaki, A.; Chan, T.C.; Hamazaki, T.S.; Asashima, M. Dullard promotes degradation and dephosphorylation of BMP receptors and is required for neural induction. Dev. Cell 2006, 11, 763-774. [CrossRef] [PubMed]

217. Hayata, T.; Ezura, Y.; Yoichi, E.; Asashima, M.; Nishinakamura, R.; Noda, M. Dullard/Ctdnep1 regulates endochondral ossification via suppression of TGF- $\beta$ signaling. J. Bone Miner. Res. 2015, 30, 318-329. [CrossRef]

218. Murakami, G.; Watabe, T.; Takaoka, K.; Miyazono, K.; Imamura, T. Cooperative inhibition of bone morphogenetic protein signaling by Smurf1 and inhibitory Smads. Mol. Biol. Cell 2003, 14, 2809-2817. [CrossRef]

219. Liang, C.; Peng, S.; Li, J.; Lu, J.; Guan, D.; Jiang, F.; Lu, C.; Li, F.; He, X.; Zhu, H.; et al. Inhibition of osteoblastic Smurf1 promotes bone formation in mouse models of distinctive age-related osteoporosis. Nat. Commun. 2018, 9, 3428. [CrossRef]

220. Murakami, K.; Etlinger, J.D. Role of SMURF1 ubiquitin ligase in BMP receptor trafficking and signaling. Cell. Signal. 2019, 54, 139-149. [CrossRef]

221. Zhu, H.; Kavsak, P.; Abdollah, S.; Wrana, J.L.; Thomsen, G.H. A SMAD ubiquitin ligase targets the BMP pathway and affects embryonic pattern formation. Nature 1999, 400, 687-693. [CrossRef] [PubMed]

222. Hassel, S.; Eichner, A.; Yakymovych, M.; Hellman, U.; Knaus, P.; Souchelnytskyi, S. Proteins associated with type II bone morphogenetic protein receptor (BMPR-II) and identified by two-dimensional gel electrophoresis and mass spectrometry. Proteomics 2004, 4, 1346-1358. [CrossRef]

223. James, A.W.; LaChaud, G.; Shen, J.; Asatrian, G.; Nguyen, V.; Zhang, X.; Ting, K.; Soo, C. A Review of the Clinical Side Effects of Bone Morphogenetic Protein-2. Tissue Eng. Part B Rev. 2016, 22, 284-297. [CrossRef] [PubMed]

224. Herford, A.S. The use of recombinant human bone morphogenetic protein-2 (rhBMP-2) in maxillofacial trauma. Chin J. Traumatol. 2017, 20, 1-3. [CrossRef] [PubMed]

225. Penn, M.; Mausner-Fainberg, K.; Golan, M.; Karni, A. High serum levels of BMP-2 correlate with BMP-4 and BMP-5 levels and induce reduced neuronal phenotype in patients with relapsing-remitting multiple sclerosis. J. Neuroimmunol. 2017, 310, 120-128. [CrossRef] [PubMed]

226. Costa, C.; Eixarch, H.; Martínez-Sáez, E.; Calvo-Barreiro, L.; Calucho, M.; Castro, Z.; Ortega-Aznar, A.; Ramón, Y.; Cajal, S.; Montalban, X.; et al. Expression of Bone Morphogenetic Proteins in Multiple Sclerosis Lesions. Am. J. Pathol. 2019, 189, 665-676. [CrossRef] [PubMed]

227. Zhang, M.; Sara, J.D.; Wang, F.L.; Liu, L.P.; Su, L.X.; Zhe, J.; Wu, X.; Liu, J.H. Increased plasma BMP-2 levels are associated with atherosclerosis burden and coronary calcification in type 2 diabetic patients. Cardiovasc. Diabetol. 2015, 14, 64. [CrossRef]

228. Morrell, N.W.; Bloch, D.B.; ten Dijke, P.; Goumans, M.J.; Hata, A.; Smith, J.; Yu, P.B.; Bloch, K.D. Targeting BMP signalling in cardiovascular disease and anaemia. Nat. Rev. Cardiol. 2016, 13, 106-120. [CrossRef]

229. Rong, S.; Zhao, X.; Jin, X.; Zhang, Z.; Chen, L.; Zhu, Y.; Yuan, W. Vascular calcification in chronic kidney disease is induced by bone morphogenetic protein- 2 via a mechanism involving the $\mathrm{Wnt} / \beta$-catenin pathway. Cell Physiol. Biochem. 2014, 34, 2049-2060. [CrossRef]

230. Wei, X.; Wu, W.; Li, L.; Lin, J.; Liu, Q.; Gan, L.; Ou, S. Bone Morphogenetic Proteins 2/4 Are Upregulated during the Early Development of Vascular Calcification in Chronic Kidney Disease. BioMed Res. Int. 2018, 2018, 8371604. [CrossRef] 
231. Zhang, Y.; Chen, X.; Qiao, M.; Zhang, B.Q.; Wang, N.; Zhang, Z.; Liao, Z.; Zeng, L.; Deng, Y.; Deng, F.; et al. Bone morphogenetic protein 2 inhibits the proliferation and growth of human colorectal cancer cells. Oncol. Rep. 2014, 32, 1013-1020. [CrossRef]

232. Horvath, L.; Henshall, S.; Kench, J.G.; Turner, J.; Golovsky, D.; Brenner, P.C.; O’Neill, G.F.; Kooner, R.; Stricker, P.D.; Grygiel, J.J.; et al. Loss of BMP2, Smad8, and Smad4 expression in prostate cancer progression. Prostate 2004, 59, 234-242. [CrossRef]

233. Bach, D.-H.; Park, H.J.; Lee, S.K. The Dual Role of Bone Morphogenetic Proteins in Cancer. Mol. Ther. Oncolytics. 2017, 8, 1-13. [CrossRef] [PubMed]

234. Dean, D.B.; Watson, J.T.; Jin, W.; Peters, C.; Enders, J.T.; Chen, A.; Moed, B.R.; Zhang, Z. Distinct functionalities of bone morphogenetic protein antagonists during fracture healing in mice. J. Anat. 2010, 216, 625-630. [CrossRef] [PubMed]

235. Chien, S.Y.; Tsai, C.H.; Liu, S.C.; Huang, C.C.; Lin, T.H.; Yang, Y.Z.; Tang, C.H. Noggin Inhibits IL-1 $\beta$ and BMP-2 Expression, and Attenuates Cartilage Degeneration and Subchondral Bone Destruction in Experimental Osteoarthritis. Cells 2020, 9, 927. [CrossRef] [PubMed]

236. Wang, Y.; Hong, S.; Li, M.; Zhang, J.; Bi, Y.; He, Y.; Liu, X.; Nan, G.; Su, Y.; Zhu, G.; et al. Noggin resistance contributes to the potent osteogenic capability of BMP9 in mesenchymal stem cells. J. Orthop. Res. 2013, 31, 1796-1803. [CrossRef] [PubMed]

237. Mumcuoglu, D.; Siverino, C.; Tabisz, B.; Kluijtmans, B.; Nickel, J. How to Use BMP-2 for Clinical Applications? A Review on Pros and Cons of Existing Delivery Strategies. Available online: https://www.oatext.com/how-to-use-bmp-2-for-clinical-applications-a-review-on-pros-and-consof-existing-delivery-strategies.php\#gsc.tab=0 (accessed on 1 August 2020).

238. King, W.J.; Krebsbach, P.H. Growth factor delivery: How surface interactions modulate release in vitro and in vivo. Adv. Drug Deliv. Rev 2012, 64, 1239-1256. [CrossRef] [PubMed]

239. Salzmann, S.N.; Lampe, L.P.; Shue, J.; Moawad, M.A.; Aichmair, A.; Hughes, A.P.; Girardi, F.P. Rapid Vertebral Osteolysis after Utilization of rhBMP-2. MOJ Orthop. Rheumatol. 2016, 6, 00238.

240. Villavicencio, A.T.; Burneikiene, S. RhBMP-2-induced radiculitis in patients undergoing transforaminal lumbar interbody fusion: Relationship to dose. Spine J. 2016, 16, 1208-1213. [CrossRef]

241. Lykissas, M.G.; Aichmair, A.; Hughes, A.P.; Sama, A.A.; Lebl, D.R.; Taher, F.; Du, J.Y.; Cammisa, F.P.; Girardi, F.P. Nerve injury after lateral lumbar interbody fusion: A review of 919 treated levels with identification of risk factors. Spine J. 2014, 14, 749-758. [CrossRef]

242. Lykissas, M.G.; Aichmair, A.; Sama, A.A.; Hughes, A.P.; Lebl, D.R.; Cammisa, F.P.; Girardi, F.P. Nerve injury and recovery after lateral lumbar interbody fusion with and without bone morphogenetic protein-2 augmentation: A cohort-controlled study. Spine J. 2014, 14, 217-224. [CrossRef]

243. Carragee, E.J.; Hurwitz, E.L.; Weiner, B.K. A critical review of recombinant human bone morphogenetic protein-2 trials in spinal surgery: Emerging safety concerns and lessons learned. Spine J. 2011, 11, 471-491. [CrossRef]

244. James, A.W.; Zara, J.N.; Zhang, X.; Askarinam, A.; Goyal, R.; Chiang, M.; Yuan, W.; Chang, L.; Corselli, M.; Shen, J.; et al. Perivascular stem cells: A prospectively purified mesenchymal stem cell population for bone tissue engineering. Stem Cells Transl. Med. 2012, 1, 510-519. [CrossRef] [PubMed]

245. Aghaloo, T.; Jiang, X.; Soo, C.; Zhang, Z.; Zhang, X.; Hu, J.; Pan, H.; Hsu, T.; Wu, B.; Ting, K. A study of the role of nell-1 gene modified goat bone marrow stromal cells in promoting new bone formation. Mol. Ther. 2007, 15, 1872-1880. [CrossRef]

246. Comer, G.C.; Smith, M.W.; Hurwitz, E.L.; Mitsunaga, K.A.; Kessler, R.; Carragee, E.J. Retrograde ejaculation after anterior lumbar interbody fusion with and without bone morphogenetic protein-2 augmentation: A 10-year cohort controlled study. Spine J. 2012, 12, 881-890. [CrossRef]

247. Hindoyan, K.; Tilan, J.; Buser, Z.; Cohen, J.R.; Brodke, D.S.; Youssef, J.A.; Park, J.B.; Yoon, S.T.; Meisel, H.J.; Wang, J.C. A Retrospective Analysis of Complications Associated with Bone Morphogenetic Protein 2 in Anterior Lumbar Interbody Fusion. Glob. Spine J. 2017, 7, 148-153. [CrossRef] [PubMed]

248. Center for Devices and Radiological Health, Food and Drug Administration. Public Health Notifications (Medical Devices)_FDA Public Health Notification: Life-Threatening Complications Associated with Recombinant Human Bone Morphogenetic Protein in Cervical Spine Fusion. Available online: http: //www.tccortho.com/pdf/FDAPublic\%20Health\%20Note.pdf (accessed on 11 February 2020). 
249. Halloran, D.; Vrathasha, V.; Durbano, H.W.; Nohe, A. Bone Morphogenetic Protein-2 Conjugated to Quantum Dot. Nanomaterials (Basel) 2020, 10, 1208. [CrossRef] [PubMed]

250. Balakin, S.; Missirlis, A.; Klemmed, B.; Lee, J.; Opitz, J.; Yeo, J.-S.; Cuniberti, G. Quantitative analysis of BMP-2 derived peptide covalently grafted onto oxidized detonation nanodiamonds. Carbon 2019, 152, 740-745. [CrossRef]

251. Zhang, D.; Potty, A.; Vyas, P.; Lane, J. The role of recombinant PTH in human fracture healing: A systematic review. J. Orthop. Trauma 2014, 28, 57-62. [CrossRef] [PubMed]

252. Chen, L.R.; Ko, N.Y.; Chen, K.H. Medical Treatment for Osteoporosis: From Molecular to Clinical Opinions. Int. J. Mol. Sci. 2019, 20, 2213. [CrossRef] [PubMed]

253. Lou, S.; Lv, H.; Yin, P.; Li, Z.; Tang, P.; Wang, Y. Combination therapy with parathyroid hormone analogs and antiresorptive agents for osteoporosis: A systematic review and meta-analysis of randomized controlled trials. Osteoporos. Int. 2019, 30, 59-70. [CrossRef]

254. Murray, T.M.; Rao, L.G.; Divieti, P.; Bringhurst, F.R. Parathyroid hormone secretion and action: Evidence for discrete receptors for the carboxyl-terminal region and related biological actions of carboxyl- terminal ligands. Endocr. Rev. 2005, 26, 78-113. [CrossRef]

255. Reeve, J.; Meunier, P.J.; Parsons, J.A.; Bernat, M.; Bijvoet, O.L.; Courpron, P.; Edouard, C.; Klenerman, L.; Neer, R.M.; Renier, J.C.; et al. Anabolic effect of human parathyroid hormone fragment on trabecular bone in involutional osteoporosis: A multicentre trial. Br. Med. J. 1980, 280, 1340-1344. [CrossRef] [PubMed]

256. Rittmaster, R.S.; Bolognese, M.; Ettinger, M.P.; Hanley, D.A.; Hodsman, A.B.; Kendler, D.L.; Rosen, C.J. Enhancement of bone mass in osteoporotic women with parathyroid hormone followed by alendronate. J. Clin. Endocrinol. Metab. 2000, 85, 2129-2134. [CrossRef]

257. Russell, R.G.; Watts, N.B.; Ebetino, F.H.; Rogers, M.J. Mechanisms of action of bisphosphonates: Similarities and differences and their potential influence on clinical efficacy. Osteoporos. Int. 2008, 19, 733-759. [CrossRef] [PubMed]

258. Lewiecki, E.M. Bisphosphonates for the treatment of osteoporosis: Insights for clinicians. Ther. Adv. Chronic Dis. 2010, 1, 115-128. [CrossRef] [PubMed]

259. Ponnapakkam, T.; Katikaneni, R.; Sakon, J.; Stratford, R.; Gensure, R.C. Treating osteoporosis by targeting parathyroid hormone to bone. Drug Discov. Today 2014, 19, 204-208. [CrossRef]

260. Burshell, A.L.; Song, J.; Dowsett, S.A.; Mershon, J.L.; Delmas, P.D.; Secrest, R.J.; Cauley, J.A. Relationship between bone mass, invasive breast cancer incidence and raloxifene therapy in postmenopausal women with low bone mass or osteoporosis. Curr. Med. Res. Opin. 2008, 24, 807-813. [CrossRef]

261. Cohen, F.J.; Lu, Y. Characterization of hot flashes reported by healthy postmenopausal women receiving raloxifene or placebo during osteoporosis prevention trials. Maturitas 2000, 34, 65-73. [CrossRef]

262. Cummings, S.R.; Eckert, S.; Krueger, K.A.; Grady, D.; Powles, T.J.; Cauley, J.A.; Norton, L.; Nickelsen, T.; Bjarnason, N.H.; Morrow, M.; et al. The effect of raloxifene on risk of breast cancer in postmenopausal women: Results from the MORE randomized trial. Multiple Outcomes of Raloxifene Evaluation. JAMA 1999, 281, 2189-2197. [CrossRef] [PubMed]

263. Davies, G.C.; Huster, W.J.; Lu, Y.; Plouffe, L.; Lakshmanan, M. Adverse events reported by postmenopausal women in controlled trials with raloxifene. Obstet. Gynecol. 1999, 93, 558-565. [CrossRef]

264. Lippman, M.E.; Cummings, S.R.; Disch, D.P.; Mershon, J.L.; Dowsett, S.A.; Cauley, J.A.; Martino, S. Effect of raloxifene on the incidence of invasive breast cancer in postmenopausal women with osteoporosis categorized by breast cancer risk. Clin. Cancer Res. 2006, 12, 5242-5247. [CrossRef]

265. Charopoulos, I.; Orme, S.; Giannoudis, P.V. The role and efficacy of denosumab in the treatment of osteoporosis: An update. Expert Opin. Drug Saf. 2011, 10, 205-217. [CrossRef] [PubMed]

266. Lewiecki, E.M. Safety and tolerability of denosumab for the treatment of postmenopausal osteoporosis. Drug Healthc. Patient Saf. 2011, 3, 79-91. [CrossRef] [PubMed]

267. Li, S.; Chen, P.; Yang, Q. Denosumab versus zoledronic acid in cases of surgically unsalvageable giant cell tumor of bone: A randomized clinical trial. J. Bone Oncol. 2019, 15, 100217. [CrossRef] [PubMed]

268. Kerschan-Schindl, K. Romosozumab: A novel bone anabolic treatment option for osteoporosis? Wien. Med. Wochenschr. 2019, 170, 124-131. [CrossRef]

269. Gingery, A.; Subramaniam, M.; Pitel, K.S.; Li, X.; Ke, H.Z.; Turner, R.T.; Iwaniec, U.T.; Hawse, J.R. Sclerostin antibody treatment rescues the osteopenic bone phenotype of TGF $\beta$ inducible early gene- 1 knockout female mice. J. Cell. Physiol. 2020, 235, 5679-5688. [CrossRef] 
270. Geusens, P.; Oates, M.; Miyauchi, A.; Adachi, J.D.; Lazaretti-Castro, M.; Ebeling, P.R.; Perez Niño, C.A.; Milmont, C.E.; Grauer, A.; Libanati, C. The Effect of 1 Year of Romosozumab on the Incidence of Clinical Vertebral Fractures in Postmenopausal Women with Osteoporosis: Results from the FRAME Study. JBMR Plus 2019, 3, e10211. [CrossRef]

271. Vrathasha, V.; Booksh, K.; Duncan, R.L.; Nohe, A. Mechanisms of Cellular Internalization of Quantum Dot ${ }^{\circledR}$ Conjugated Bone Formation Mimetic Peptide CK2.3. Nanomaterials (Basel) 2018, 8, 513. [CrossRef]

272. Siddiqui-Jain, A.; Drygin, D.; Streiner, N.; Chua, P.; Pierre, F.; O’Brien, S.E.; Bliesath, J.; Omori, M.; Huser, N.; Ho, C.; et al. CX-4945, an orally bioavailable selective inhibitor of protein kinase CK2, inhibits prosurvival and angiogenic signaling and exhibits antitumor efficacy. Cancer Res. 2010, 70, 10288-10298. [CrossRef]

273. Pierre, F.; Chua, P.C.; O’Brien, S.E.; Siddiqui-Jain, A.; Bourbon, P.; Haddach, M.; Michaux, J.; Nagasawa, J.; Schwaebe, M.K.; Stefan, E.; et al. Pre-clinical characterization of CX-4945, a potent and selective small molecule inhibitor of CK2 for the treatment of cancer. Mol. Cell. Biochem. 2011, 356, 37-43. [CrossRef]

274. Son, Y.H.; Moon, S.H.; Kim, J. The protein kinase 2 inhibitor CX-4945 regulates osteoclast and osteoblast differentiation in vitro. Mol. Cells 2013, 36, 417-423. [CrossRef]

275. Zhang, X.; Guo, W.G.; Cui, H.; Liu, H.Y.; Zhang, Y.; Müller, W.E.; Cui, F.Z. In vitro and in vivo enhancement of osteogenic capacity in a synthetic BMP-2 derived peptide-coated mineralized collagen composite. J. Tissue Eng. Regen. Med. 2016, 10, 99-107. [CrossRef] [PubMed]

276. Wang, C.; Liu, Y.; Fan, Y.; Li, X. The use of bioactive peptides to modify materials for bone tissue repair. Regen. Biomater. 2017, 4, 191-206. [CrossRef] [PubMed]

277. Kim, M.J.; Lee, B.; Yang, K.; Park, J.; Jeon, S.; Um, S.H.; Kim, D.I.; Im, S.G.; Cho, S.W. BMP-2 peptide-functionalized nanopatterned substrates for enhanced osteogenic differentiation of human mesenchymal stem cells. Biomaterials 2013, 34, 7236-7246. [CrossRef] [PubMed]

278. Moeinzadeh, S.; Barati, D.; Sarvestani, S.K.; Karimi, T.; Jabbari, E. Experimental and computational investigation of the effect of hydrophobicity on aggregation and osteoinductive potential of BMP-2-derived peptide in a hydrogel matrix. Tissue Eng. Part A 2015, 21, 134-146. [CrossRef]

279. Ma, Y.; Policastro, G.M.; Li, Q.; Zheng, J.; Jacquet, R.; Landis, W.J.; Becker, M.L. Concentration-Dependent hMSC Differentiation on Orthogonal Concentration Gradients of GRGDS and BMP-2 Peptides. Biomacromolecules 2016, 17, 1486-1495. [CrossRef]

280. Greenspan, S.; Field-Munves, E.; Tonino, R.; Smith, M.; Petruschke, R.; Wang, L.; Yates, J.; de Papp, A.E.; Palmisano, J. Tolerability of once-weekly alendronate in patients with osteoporosis: A randomized, double-blind, placebo-controlled study. Mayo Clin. Proc. 2002, 77, 1044-1052. [CrossRef]

281. Eisman, J.A.; Rizzoli, R.; Roman-Ivorra, J.; Lipschitz, S.; Verbruggen, N.; Gaines, K.A.; Melton, M.E. Upper gastrointestinal and overall tolerability of alendronate once weekly in patients with osteoporosis: Results of a randomized, double-blind, placebo-controlled study. Curr. Med. Res. Opin. 2004, 20, 699-705. [CrossRef]

282. Harris, S.T.; Watts, N.B.; Genant, H.K.; McKeever, C.D.; Hangartner, T.; Keller, M.; Chesnut, C.H.; Brown, J.; Eriksen, E.F.; Hoseyni, M.S.; et al. Effects of risedronate treatment on vertebral and nonvertebral fractures in women with postmenopausal osteoporosis: A randomized controlled trial. Vertebral Efficacy With Risedronate Therapy (VERT) Study Group. J.AMA 1999, 282, 1344-1352. [CrossRef]

283. Chesnut, C.H.; Skag, A.; Christiansen, C.; Recker, R.; Stakkestad, J.A.; Hoiseth, A.; Felsenberg, D.; Huss, H.; Gilbride, J.; Schimmer, R.C.; et al. Effects of oral ibandronate administered daily or intermittently on fracture risk in postmenopausal osteoporosis. J. Bone Miner. Res. 2004, 19, 1241-1249. [CrossRef]

284. Chesnut, C.H.; Ettinger, M.P.; Miller, P.D.; Baylink, D.J.; Emkey, R.; Harris, S.T.; Wasnich, R.D.; Watts, N.B.; Schimmer, R.C.; Recker, R.R. Ibandronate produces significant, similar antifracture efficacy in North American and European women: New clinical findings from BONE. Curr. Med. Res. Opin. 2005, 21, 391-401. [CrossRef]

285. Delmas, P.D.; Recker, R.R.; Chesnut, C.H.; Skag, A.; Stakkestad, J.A.; Emkey, R.; Gilbride, J.; Schimmer, R.C.; Christiansen, C. Daily and intermittent oral ibandronate normalize bone turnover and provide significant reduction in vertebral fracture risk: Results from the BONE study. Osteoporos. Int. 2004, 15, 792-798. [CrossRef]

286. Cardwell, C.R.; Abnet, C.C.; Cantwell, M.M.; Murray, L.J. Exposure to oral bisphosphonates and risk of esophageal cancer. JAMA 2010, 304, 657-663. [CrossRef]

287. Haber, S.L.; McNatty, D. An evaluation of the use of oral bisphosphonates and risk of esophageal cancer. Ann. Pharmacother. 2012, 46, 419-423. [CrossRef] 
288. Pazianas, M.; Cooper, C.; Ebetino, F.H.; Russell, R.G. Long-term treatment with bisphosphonates and their safety in postmenopausal osteoporosis. Ther. Clin. Risk Manag. 2010, 6, 325-343. [CrossRef]

289. Wysowski, D.K. Reports of esophageal cancer with oral bisphosphonate use. N. Engl. J. Med. 2009, 360, 89-90. [CrossRef] [PubMed]

290. Khosla, S.; Burr, D.; Cauley, J.; Dempster, D.W.; Ebeling, P.R.; Felsenberg, D.; Gagel, R.F.; Gilsanz, V.; Guise, T.; Koka, S.; et al. Bisphosphonate-associated osteonecrosis of the jaw: Report of a task force of the American Society for Bone and Mineral Research. J. Bone Miner. Res. 2007, 22, 1479-1491. [CrossRef] [PubMed]

291. Marx, R.E.; Cillo, J.E.; Ulloa, J.J. Oral bisphosphonate-induced osteonecrosis: Risk factors, prediction of risk using serum CTX testing, prevention, and treatment. J. Oral Maxillofac. Surg. 2007, 65, 2397-2410. [CrossRef]

292. Novince, C.M.; Ward, B.B.; McCauley, L.K. Osteonecrosis of the jaw: An update and review of recommendations. Cells Tissues Organs 2009, 189, 275-283. [CrossRef] [PubMed]

293. Odvina, C.V.; Zerwekh, J.E.; Rao, D.S.; Maalouf, N.; Gottschalk, F.A.; Pak, C.Y. Severely suppressed bone turnover: A potential complication of alendronate therapy. J. Clin. Endocrinol. Metab. 2005, 90, 1294-1301. [CrossRef]

294. Bone, H.G.; Hosking, D.; Devogelaer, J.P.; Tucci, J.R.; Emkey, R.D.; Tonino, R.P.; Rodriguez-Portales, J.A.; Downs, R.W.; Gupta, J.; Santora, A.C.; et al. Ten years' experience with alendronate for osteoporosis in postmenopausal women. N. Engl. J. Med. 2004, 350, 1189-1199. [CrossRef]

295. Khan, M.; Cheung, A.M.; Khan, A.A. Drug-Related Adverse Events of Osteoporosis Therapy. Endocrinol. Metab. Clin. N. Am. 2017, 46, 181-192. [CrossRef] [PubMed]

296. Vogel, V.G.; Qu, Y.; Wong, M.; Mitchell, B.; Mershon, J.L. Incidence of invasive breast cancer in postmenopausal women after discontinuation of long-term raloxifene administration. Clin. Breast Cancer 2009, 9, 45-50. [CrossRef] [PubMed]

297. Cosman, F.; Crittenden, D.B.; Ferrari, S.; Lewiecki, E.M.; Jaller-Raad, J.; Zerbini, C.; Milmont, C.E.; Meisner, P.D.; Libanati, C.; Grauer, A. Romosozumab FRAME Study: A Post Hoc Analysis of the Role of Regional Background Fracture Risk on Nonvertebral Fracture Outcome. J. Bone Miner. Res. 2018, 33, 1407-1416. [CrossRef] [PubMed]

298. Langdahl, B.L.; Libanati, C.; Crittenden, D.B.; Bolognese, M.A.; Brown, J.P.; Daizadeh, N.S.; Dokoupilova, E.; Engelke, K.; Finkelstein, J.S.; Genant, H.K.; et al. Romosozumab (sclerostin monoclonal antibody) versus teriparatide in postmenopausal women with osteoporosis transitioning from oral bisphosphonate therapy: A randomised, open-label, phase 3 trial. Lancet 2017, 390, 1585-1594. [CrossRef]

299. Shakeri, A.; Adanty, C. Romosozumab (sclerostin monoclonal antibody) for the treatment of osteoporosis in postmenopausal women: A review. J. Popul. Ther. Clin. Pharmacol. 2020, 27, e25-e31. [CrossRef]

300. Sølling, A.S.K.; Harsløf, T.; Langdahl, B. The clinical potential of romosozumab for the prevention of fractures in postmenopausal women with osteoporosis. Ther. Adv. Musculoskelet. Dis. 2018, 10, 105-115. [CrossRef] [PubMed]

301. Neer, R.M.; Arnaud, C.D.; Zanchetta, J.R.; Prince, R.; Gaich, G.A.; Reginster, J.Y.; Hodsman, A.B.; Eriksen, E.F.; Ish-Shalom, S.; Genant, H.K.; et al. Effect of parathyroid hormone (1-34) on fractures and bone mineral density in postmenopausal women with osteoporosis. N. Engl. J. Med. 2001, 344, 1434-1441. [CrossRef]

302. Miller, P.D.; Bilezikian, J.P.; Diaz-Curiel, M.; Chen, P.; Marin, F.; Krege, J.H.; Wong, M.; Marcus, R. Occurrence of hypercalciuria in patients with osteoporosis treated with teriparatide. J. Clin. Endocrinol. Metab. 2007, 92, 3535-3541. [CrossRef]

303. Miller, P.D.; Schwartz, E.N.; Chen, P.; Misurski, D.A.; Krege, J.H. Teriparatide in postmenopausal women with osteoporosis and mild or moderate renal impairment. Osteoporos. Int. 2007, 18, 59-68. [CrossRef]

304. Bégin, M.J.; Ste-Marie, L.G.; Coupal, L.; Ethier, J.; Räkel, A. Hypomagnesemia during Teriparatide Treatment in Osteoporosis: Incidence and Determinants. J. Bone Miner. Res. 2018, 33, 1444-1449. [CrossRef]

305. Thiruchelvam, N.; Randhawa, J.; Sadiek, H.; Kistangari, G. Teriparatide induced delayed persistent hypercalcemia. Case Rep. Endocrinol. 2014, 2014, 802473. [CrossRef] [PubMed]

306. Owens, P.; Pickup, M.W.; Novitskiy, S.V.; Giltnane, J.M.; Gorska, A.E.; Hopkins, C.R.; Hong, C.C.; Moses, H.L. Inhibition of BMP signaling suppresses metastasis in mammary cancer. Oncogene 2015, 34, 2437-2449. [CrossRef] [PubMed] 
307. Lin, T.; Wang, X.L.; Zettervall, S.L.; Cai, Y.; Guzman, R.J. Dorsomorphin homologue 1, a highly selective small-molecule bone morphogenetic protein inhibitor, suppresses medial artery calcification. J. Vasc. Surg. 2017, 66, 586-593. [CrossRef]

308. Hao, J.; Lee, R.; Chang, A.; Fan, J.; Labib, C.; Parsa, C.; Orlando, R.; Andresen, B.; Huang, Y. DMH1, a small molecule inhibitor of BMP type i receptors, suppresses growth and invasion of lung cancer. PLoS ONE 2014, 9, e90748. [CrossRef] [PubMed] article distributed under the terms and conditions of the Creative Commons Attribution (CC BY) license (http://creativecommons.org/licenses/by/4.0/). 